\title{
Geochemical evolution of groundwater on Saturna Island, British Columbia
}

\author{
D.M. Allen and M. Suchy
}

\begin{abstract}
A detailed geochemical study of surface waters, spring waters, and groundwaters was undertaken to examine the geochemical evolution of groundwater on Saturna Island, British Columbia. The purpose of the study was to characterize the nature and occurrence of saline waters and to provide insight on chemical processes that lead to salinization in the fractured sedimentary bedrock aquifers of this small island. Major ion chemistry shows that groundwater is recharged locally but mixes with saline waters that occur at depth or near the coast. Simple mixing is complicated by cation exchange (between calcium-rich waters and sodium-rich exchange sites offered by mudstone beds) and results in a spatially variable hydrochemical composition that is dependent on the island topography and geological framework (structural, sedimentological, and glacial), in combination with groundwater use patterns. Sodium, present at exchange sites, is speculated to be a remnant of ocean water intrusion during the Pleistocene, when the island was submerged. As a result of its high mobility and conservative nature, chloride (and sulphate) has been flushed from the shallow bedrock during a process of natural desalinization but may remain trapped in the pores and fractures at depth. Modern salt-water intrusion, brought about by increased development on the island, is now competing with natural desalinization along the coast and has left many drinking-water supplies contaminated.
\end{abstract}

Résumé : Une étude géochimique détaillée des eaux de surface, des eaux de sources et des eaux souterraines a été entreprise pour examiner l'évolution géochimique de l'eau souterraine sur l'île de Saturna, en Colombie Britannique. Le but de l'étude était de caractériser la nature et l'occurrence d'eau saline et de comprendre les processus chimiques qui conduisent à la salinisation des aquifères situés dans la roche mère sédimentaire fracturée de cette petite île. La chimie des ions majeurs montre que l'eau souterraine est rechargée localement, mais qu'elle se mélange aux eaux salines qui se trouvent en profondeur ou près de la côte. Le simple mélange se complique par l'échange de cations (entre les eaux riches en calcium et les sites d'échanges riches en sodium des lits de mudstone); il en résulte une composition hydrochimique à variation spatiale qui dépend de la topographie de l'île et de son cadre géologique (structural, sédimentologique et glacial) combinés aux patrons d'utilisation de l'eau souterraine. Nous proposons que le sodium, présent aux sites d'échanges, est un restant d'intrusion d'eau océanique au cours du Pléistocène, lorsque l'île était submergée. En raison de sa grande mobilité et de sa nature conservatrice, le chlorure a été retiré de la roche-mère à faible profondeur durant un processus de dessalement mais, en profondeur, il peut demeurer emprisonné dans les pores et les fractures (idem pour le sulfate). L'intrusion d'eau saline moderne, amenée par la croissance du développement sur l'île, est maintenant en compétition avec le dessalement naturel le long de la côte et elle contamine plusieurs sources d'eau potable.

[Traduit par la Rédaction]

\section{Introduction}

Saturna Island is the most eastern and southern of the Canadian Gulf Islands and is situated immediately north of the international border near the southern end of the Strait of Georgia. Inhabited islands surrounding Saturna Island include the Pender Islands to the southwest, Mayne Island to the northwest (Fig. 1), and the San Juan Islands (United States) to the southeast. Tumbo Island to the north is a small uninhabited island that is being considered by the Provincial Government of British Columbia for a provincial park (Fig. 2).
Saturna Island is $31 \mathrm{~km}^{2}$ in area and is extensively developed along several segments of shoreline. It sustains a population of approximately 315 residents year round, although this figure inflates during the summer as part-time residents and visitors arrive.

Saturna Island, as with many other of the Gulf Islands, derives its potable water primarily from groundwater. Groundwater quality on Saturna Island, several other of the Gulf Islands, and the San Juan Islands to the south is extremely variable and is affected locally by high salinity. In addition, water levels are reduced substantially (as indicated by the occurrence

Received August 18, 1999. Accepted December 12, 2000. Published on the NRC Research Press Web site at http://cjes.nrc.ca on July 13, 2001.

Paper handled by Associate Editor R. Renaut.

D.M. Allen. ${ }^{1}$ Department of Earth Sciences, Simon Fraser University, Burnaby, BC V5A 1S6, Canada.

M. Suchy. Dillon Consulting, Box 978, Iqaluit, Nunavut X0A 0H0, Canada.

${ }^{1}$ Corresponding author (e-mail: dallen@sfu.ca). 
Fig. 1. Regional setting of the Nanaimo Group and Saturna Island. Geology from Mustard (1994).

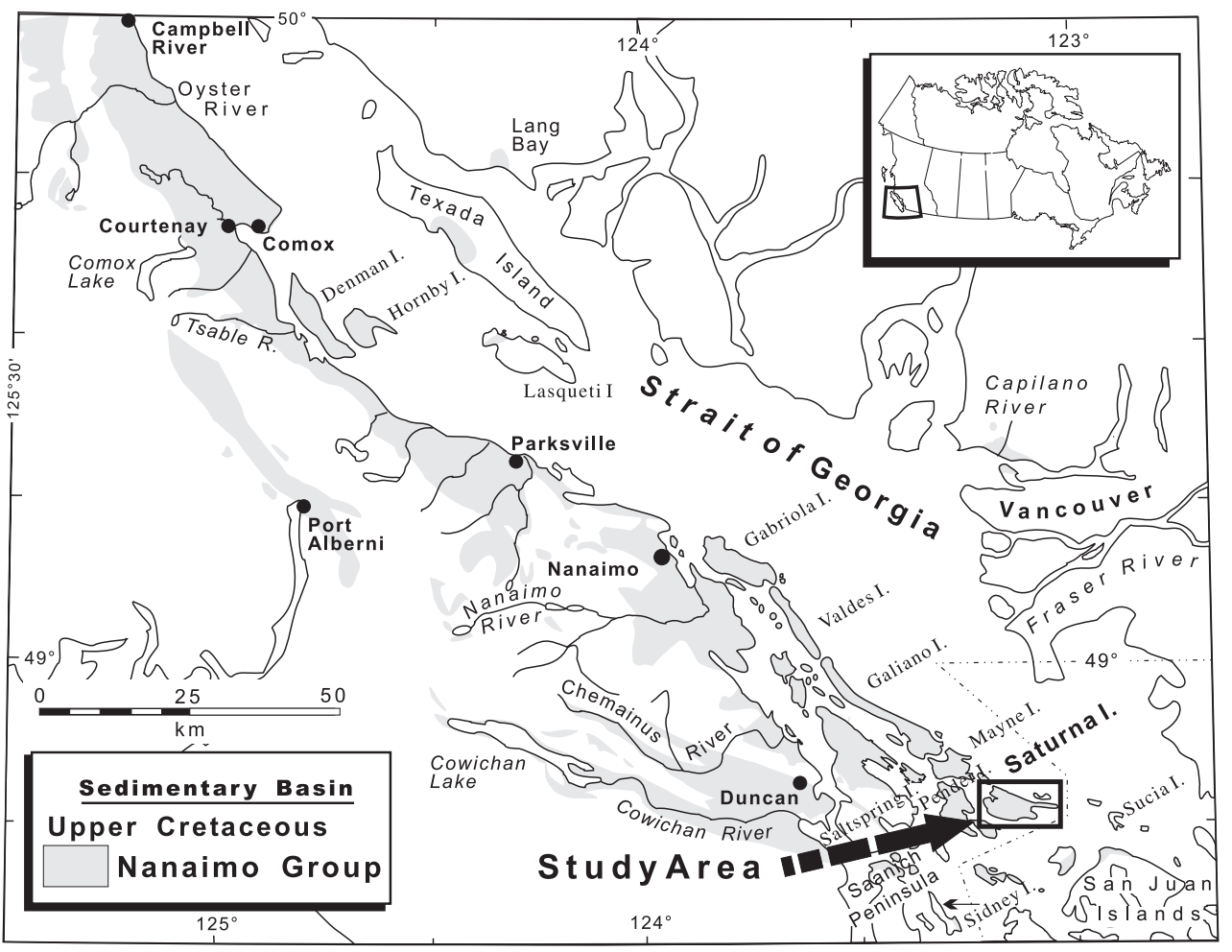

of dry wells) in some areas during the summer months when precipitation is low. Further, the quality of water during the summer has also been reported to deteriorate.

Recent increases in the reported number of cases of groundwater deterioration, particularly to the south in the San Juan Islands, suggest that salt-water intrusion may be occurring in many areas and that water-quality variations may be more complex on the Gulf Islands than originally anticipated.

The purpose of this study was to examine the geochemical evolution of groundwater on Saturna Island, British Columbia, to characterize the nature and occurrence of saline waters and provide insight on physical processes that control salinization in fractured sedimentary bedrock aquifers on a small island. The complex geology of the area (structural, sedimentological, and glacial) in combination with groundwater use patterns are expected to have a significant influence on both the spatial distribution of saline waters and the mechanisms of salinization. Results of the study will be used to provide planning guidance to the Saturna Island Local Trust Committee (part of the Islands Trust, a regional governing body).

This paper describes the results of a detailed geochemical study of the groundwaters, surface waters, and spring waters of Saturna Island, which was carried out to address the following: $(i)$ the spatial variability of the hydrochemical data as it relates to groundwater salinity, (ii) possible interactions of groundwaters with bedrock and surficial materials, (iii) the chemical evolution of natural groundwater, and (iv) possible sources of saline water. Details concerning the geological influence on the spatial variability of groundwater chemistry can be found elsewhere (Suchy 1998). Results of a detailed stable isotope study conducted in conjunction with this study will be forthcoming (Allen and Clark²).

\section{Study area}

\section{Bedrock geology}

The bedrock geology of Saturna Island is composed solely of sedimentary rocks belonging to the Late Cretaceous Nanaimo Group ( 91-66 Ma). The strata consist mainly of alternating interbeds of sandstone, shale, and some conglomerate. The conglomerates, sandstones, and siltstones are more commonly exposed because the shale tends to weather rapidly. The Nanaimo Group strata are exposed on Vancouver Island, the Gulf Islands, and small portions of the San Juan Islands of Washington State (Fig. 1) and are generally divided into 10 formations. Lithofacies descriptions provided in Table 1 are summarized from Mustard (1994). The strata of Tumbo Island, north of Saturna Island, are Tertiary in age (Fig. 3; P.S. Mustard, personal communication, 1994).

The Nanaimo Group sequence was deformed by compression into a fold and thrust belt during the Middle Eocene (Mustard 1994; England and Hiscott 1992) and was later uplifted and eroded during the Neogene, concurrent with uplift of the Coast Belt to the east (Mustard 1994). The resulting fractured syncline-anticline combination is evident in the present outcrop pattern on Saturna Island (Fig. 3). The two fold axes (Fontaine 1982) control the location of two prominent ridges on the island: Brown Ridge (overlooking Plumper Sound) and the second unnamed ridge running the length of

\footnotetext{
${ }^{2}$ D.M. Allen and I.D. Clark. In preparation. Using stable isotopes of oxygen, hydrogen and sulphur to determine the origin of groundwaters on the Gulf Islands, British Columbia.
} 
Table 1. Lithofacies descriptions of the Nanaimo Group strata (after Mustard 1994).

\begin{tabular}{|c|c|c|}
\hline Formation & Symbol $^{a}$ & Description \\
\hline Protection & $P$ & $\begin{array}{l}\text { Primarily sandstone with interbeds } \\
\text { of mudstone near the upper } \\
\text { contact; minor quantities of } \\
\text { conglomerate with subrounded } \\
\text { pebble- and cobble-sized clasts }\end{array}$ \\
\hline Cedar District & $\mathrm{CD}$ & $\begin{array}{l}\text { Lower sequence begins with silty } \\
\text { shale with a few fine-grained } \\
\text { sandstone layers overlain by fine- } \\
\text { to medium-grained sandstone with } \\
\text { subangular quartz clasts with } \\
\text { some interbeds }\end{array}$ \\
\hline de Courcy & $\mathrm{dC}$ & $\begin{array}{l}\text { Mainly brown-grey sandstone, } \\
\text { subrounded, fine- to medium- } \\
\text { grained quartz sand with minor } \\
\text { feldspar, mica, and carbonaceous } \\
\text { material; base is mostly massive } \\
\text { pebbly sandstone; very resistant } \\
\text { to weathering }\end{array}$ \\
\hline Northumberland & $\mathrm{N}$ & $\begin{array}{l}\text { Mostly interfingerings of sandstone } \\
\text { and shale beds; beds higher in } \\
\text { the succession are graded } \\
\text { sandstone-siltstone-shale and } \\
\text { are } 2-15 \mathrm{~cm} \text { thick }\end{array}$ \\
\hline Geoffrey & $\mathrm{Ge}$ & $\begin{array}{l}\text { Well-sorted sandstone with minor } \\
\text { quantities of coarse conglomer- } \\
\text { ate; shale beds are prominent } \\
\text { throughout }\end{array}$ \\
\hline Spray & S & $\begin{array}{l}\text { Grey mudstone and siltstone with } \\
\text { minor sandstone interbeds }\end{array}$ \\
\hline
\end{tabular}

${ }^{a}$ Symbols used in Figs. 3 and 4 to identify formations.

the north side of the island (Fig. 3). Strata dip angles range from almost horizontal atop the anticline to $49^{\circ}$ on the north side of the island (Fig. 3). Outcrop patterns for the different formations, in combination with strata dip and the relative orientation of the beds with respect to recharge areas, can be expected to influence groundwater flow patterns and possibly groundwater geochemistry.

There are two major faults on Saturna Island. The first is Harris Fault, which strikes NNE-SSW, crosses Brown Ridge between Mount Fisher and Mount Warburton Pike, and apparently ends at the anticline fold axis. The second has the same strike and separates Mount David from Mount Elford (Fig. 3). Both are high-angle, oblique-slip faults with minimal displacement (P.S. Mustard, personal communication, 1994). Major faults may represent regional barriers and (or) preferred pathways for circulating groundwater (Allen and Michel 1998, 1999) and thus may influence groundwater geochemistry on a regional scale.

The porosity of the Nanaimo Group rocks on Saturna Island is in general extremely low $(<5 \%)$, and permeability is likely derived from fractures. The proportion of water available for use depends on whether the fractures are present, their size, their abundance, and whether they are free of clay or other fine-grained sediments or secondary mineralization. In areas that host poorly fractured bedrock or where no major fractures are intersected by a well, the groundwater yield will be low, as permeability is much reduced. On Saturna Island, fracture intensity appears to be an essential factor controlling the availability of groundwater. Often found in conjunction with shale beds, these fractured intervals produce the highest quantities of groundwater for domestic use. According to driller's logs, principal water-bearing aquifers are fractured shale beds and geological contacts. In addition, dominant fracture sets and fault zones may also provide the permeability necessary to support high-yielding wells.

\section{Surficial geology}

Pleistocene and Holocene deposits cover much of Saturna Island. The Pleistocene sediments include moraine and glaciofluvial material that accumulated during advance and retreat of the Fraser Glaciation at approximately 20000 BP (Clague 1986). Holocene sediments (fluvial, organic, and colluvium) cover bedrock and older glacial sediments. The unconsolidated surficial deposits are generally less than $2 \mathrm{~m}$ thick, and surficial material overlying bedrock does not exceed $6 \mathrm{~m}$ (Dixon-Warren 1997). Furthermore, the sediments tend to be thickest at the bottom of valleys and are generally only present as thin veneers on the upper portions of hills and ridges.

During the Pleistocene, glacial cover depressed the land by as much as $300 \mathrm{~m}$ below present-day sea level along the Strait of Georgia (Clague 1983). During the postglacial period, eustatic sea-level rise, along with residual land depression, caused the island to remain submerged (Mathews et al. 1970). Evidence, such as relic wave-cut platforms and an exposed glaciomarine diamicton on Saturna Island, confirm interpretations of submergence (Dixon-Warren 1997). On neighbouring Mayne Island, Dakin et al. (1983) estimated that the island was submerged below the present-day $150 \mathrm{~m}$ elevation. Mathews et al. (1970) estimated that ice cover left the area very rapidly at $13000 \mathrm{BP}$, and that by $12000 \mathrm{BP}$ the land had risen to present-day sea level. Since that time the land surface elevation has not changed significantly.

\section{Climate and hydrology}

Mean annual precipitation on Saturna Island and neighbouring Gulf Islands is similar to Victoria ( $811 \mathrm{~mm} / \mathrm{year})$. The winter months bring the majority of precipitation (Fontaine 1982); $75 \%$ of the precipitation falls from October to March. During the summer months there is reduced precipitation, which can be attributed in part to the "rain-shadow effect" created by the Olympic Peninsula in the United States to the south and mountains on Vancouver Island. Mean annual temperature in Victoria is $10^{\circ} \mathrm{C}$ (Environment Canada 1982).

The surface water drainage system consists of Lyall Creek, one small creek that drains into Narvaez Bay, and several small ephemeral streams. There are no naturally formed lakes on Saturna. Money Lake, which is man-made, provides municipal water to many households in the Lyall Harbour area. Several swamps are situated throughout the island, both at high and low elevations.

Topographically high terrain can be expected to act as recharge areas for much of the island. The hydraulic potential developed at these high elevations can be expected to generate a sufficient hydraulic gradient to direct infiltrating groundwater towards valley bottoms and the coast (Fig. 4); 
Fig. 2. Map showing development density, sample locations, and groundwater-flow regions.

\section{LEGEND}

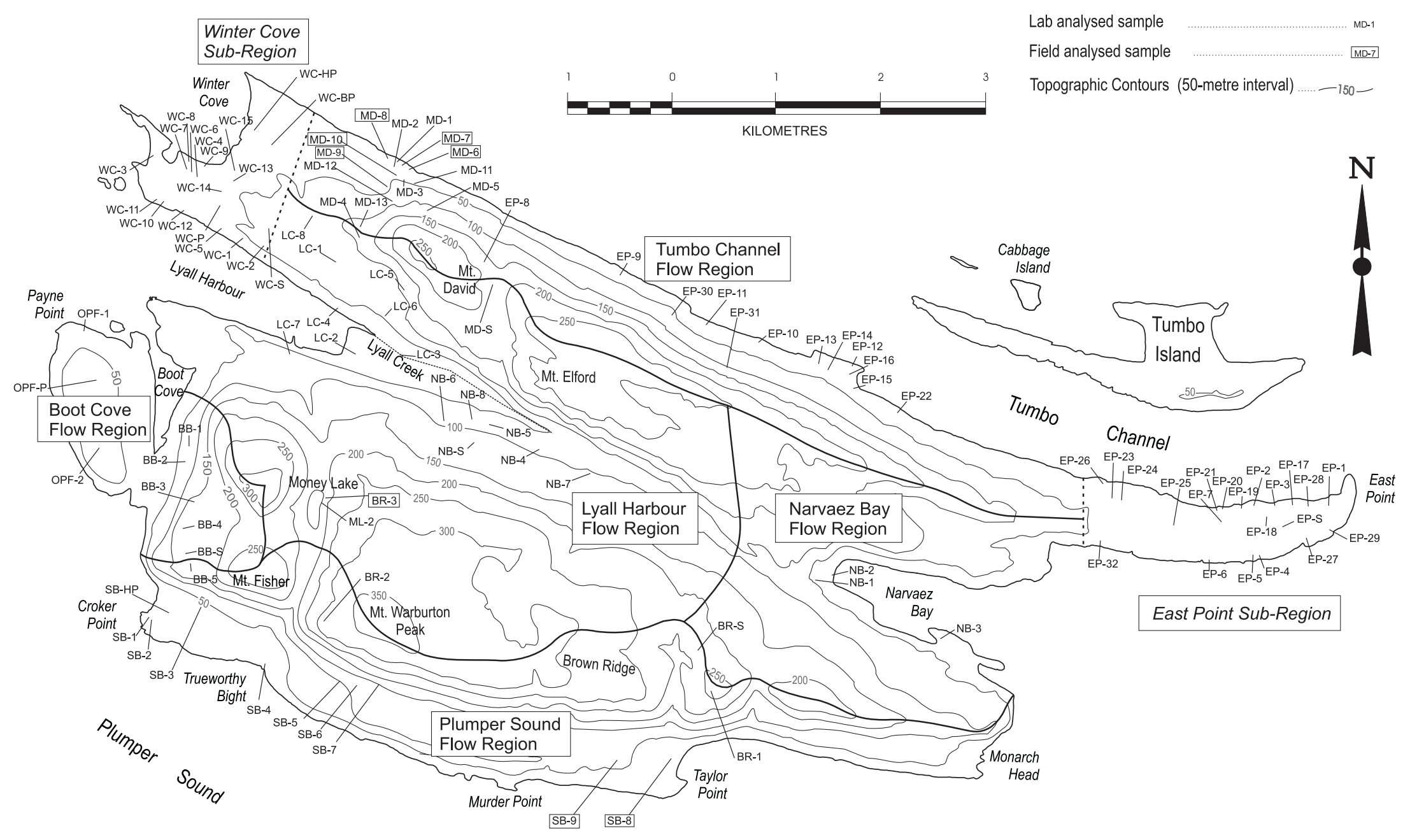




\section{SYMBOLS}

Geological Contact

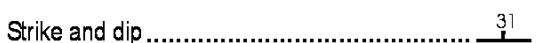

Faults

Axial trace of antiform fold

Axial trace of synform fold.

Topographic Contours (50-metre interva)

Line of Geological cross-section.
LEGEND

Tertiary

C Chuckanut

Cretaceous

S Spray

$\mathrm{Geg}$ Geoffrey

$\mathrm{N}$ Northumberland

$\because \mathrm{d} \cdot{ }^{\circ}$ de Courcy

CD Cedar District

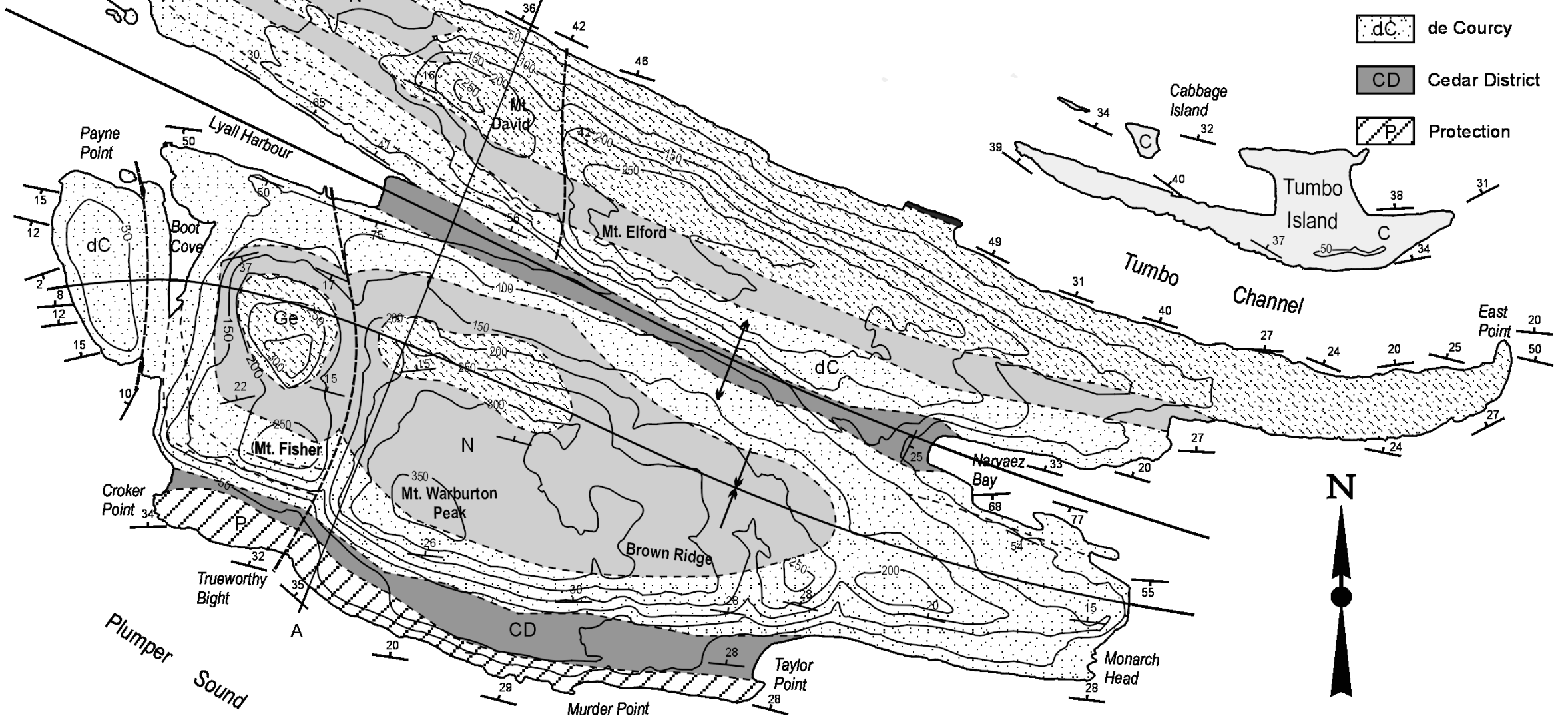


Fig. 4. Geologic cross section and idealized groundwater-flow paths. See Fig. 3 for location of cross section.
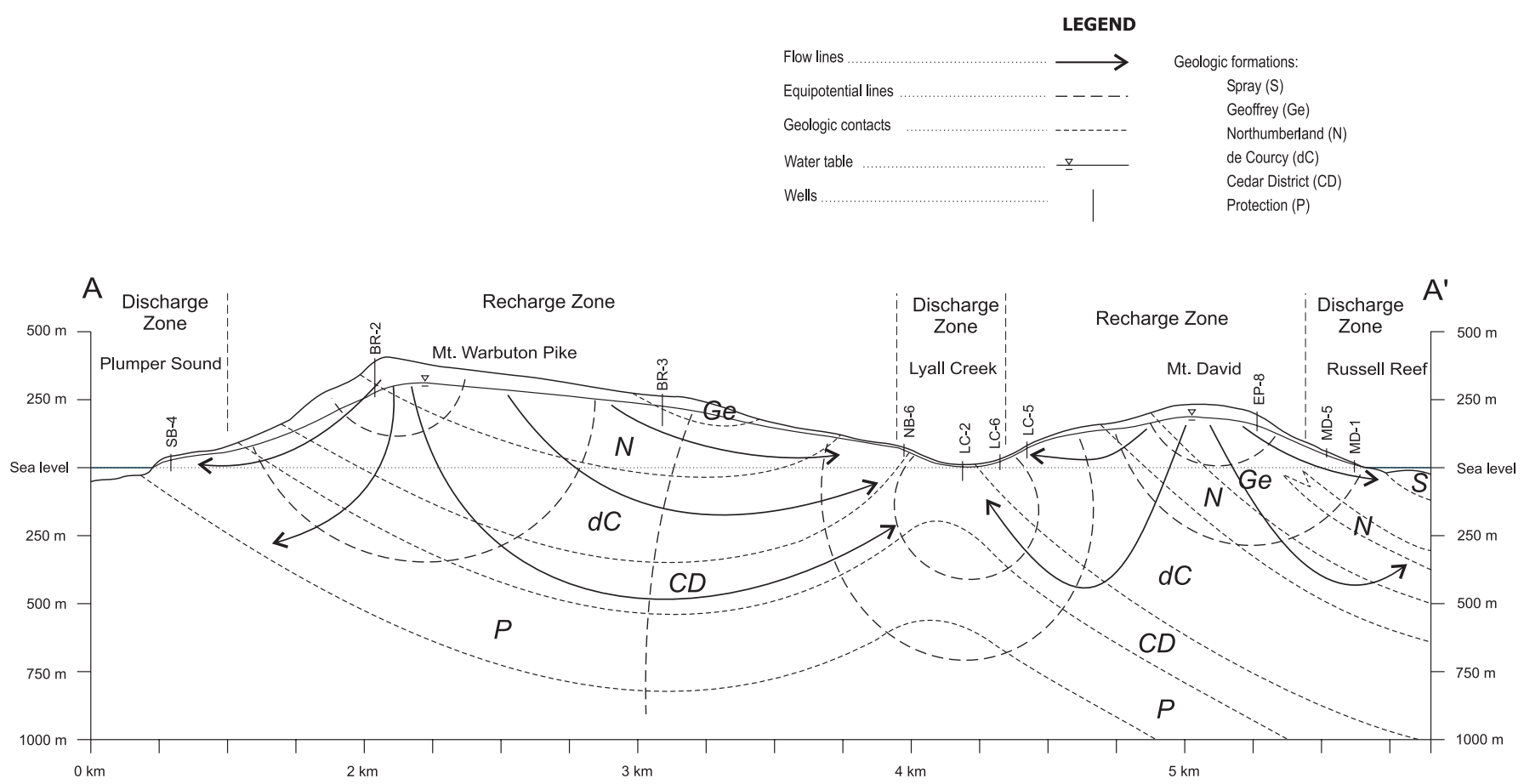

however, the nature of the flow paths and the rate of groundwater flow are largely unknown. In discharge zones, the hydraulic head is close to the surface (or above), whereas in recharge zones the water table as seen in wells is far deeper. For example, the static water level in a well on Brown Ridge is greater than $100 \mathrm{~m}$ below the surface.

Areas of dense forest floor coverage on northern slopes of the island have minimal surface runoff during short periods of precipitation and can be expected to act as significant groundwater recharge areas. In fact, groundwater discharge along the base of the northern slopes is significant, as evidenced by flowing wells and an abundance of small seeps. On the dry southern slopes with no forest floor vegetation, there is greater susceptibility for overland flow, and thus lower amounts of infiltration. Similarly, rugged terrain such as the steep southern cliffs of Brown Ridge, which act as recharge zones for the low-lying ground between Croker Point and Taylor Point, also does not permit much infiltration.

Lack of precipitation from June to October has been reported to cause groundwater quality and availability problems. During the summer of 1998, several wells on Saturna Island, both in low-lying shoreline areas and topographically higher areas, experienced depressed water levels (dropped below pump levels in some instances), and many residents complained of reduced water quality (typically a higher turbidity). Because of the change in stored water volume, water quality can be expected to deteriorate during summer but improve during the fall and winter months (Hodge 1985). We propose an explanation that during dry seasons the reduced water quality and quantity are related to accessing deeper, and possibly lower permeability fractures, which are less frequently accessed for water supply.

\section{Groundwater development}

Of the 250 wells on Saturna Island, most are located in the areas of Lyall Harbour, Boot Cove, and East Point penin-

sula. At the time of this study (summer 1998) the approximate number of wells was 150 in use, 50 not yet in production, and approximately 50 abandoned. Lyall Harbour has approximately 30 abandoned wells, most of which are shallow $(<15 \mathrm{~m})$. In 1985 the Boot Cove area had only eight wells, most of which were abandoned because of high salinity and because the area, along with Lyall Harbour, became serviced by municipal water from Money Lake. On East Point peninsula, at least five wells have been abandoned due to high salinization. Approximately 30 wells were drilled in the Winter Cove area in the early 1980s; however, most are not yet in production. Continuing development is evident by the 13 wells that were installed in August 1998 near Russell Reef on the north side of the island. The remainder of Saturna Island remains largely undeveloped.

\section{Methodology}

\section{Sampling program}

A total of 84 water samples were collected from wells, swamps, ponds, and springs on Saturna Island. Most springs occurred as seeps at the base of cliffs or issued from depressions in valleys. Most well waters were sampled directly from outdoor taps (ensuring that these bypassed any water-softening devices). Water was allowed to run for approximately $10 \mathrm{~min}$ to purge several well volumes. Some wells (those without pumps) were sampled using a bailer or portable pump (Grundfos) and were purged by removing two to three well volumes. Swamp and pond waters were collected using a grab sampler, and springs were sampled at the source where possible. Additional chemical data were supplied from waters sampled the previous summer (1997). These included 23 water samples from various wells and surface water supplies as well as samples taken during a few pump tests. The location of all samples is shown in Fig. 2.

Samples sent for laboratory analysis were collected in a 
$1 \mathrm{~L}$ bottle for anion analysis and a $500 \mathrm{~mL}$ bottle for metal analysis. Samples for dissolved metals and total alkalinity were first filtered $(0.45 \mu \mathrm{m}$ nylon membrane). Only half of those samples collected in June 1998 were preserved with nitric acid; the remaining samples were kept cool and later acidified at the laboratory. The inconsistency in sampling protocol does not appear to have affected the results. Field parameters ( $\mathrm{pH}$, electrical conductivity (EC), total dissolved solids (TDS), and temperature) were measured during collection (the probes were inserted into a container and measurements allowed to stabilize) or immediately following sample collection to acquire representative values of ambient aquifer conditions. All instruments were calibrated daily. Field total alkalinity was measured by acid titration to a $\mathrm{pH}$ of 4.5 , which corresponds approximately with the equivalence point for the conversion of bicarbonate ion to carbonic acid, and TDS was measured using a Hanna ${ }^{\circledR} 10 / 1990$ probe (TDS provided a quick verification of EC). Temperature and $\mathrm{pH}$ were both measured using a Hanna ${ }^{\circledR}$ HI 9083, and the conductivity metre used was a Hanna ${ }^{\circledR} \mathrm{H}$ 9033. Total alkalinity was also measured at an analytical laboratory (discussed in Data analysis). The average deviation between laboratory and field determination of total alkalinity is $18.6 \%$.

Field sampling containers, filter chambers, and probes were rinsed with distilled water between samples. In addition to two duplicate samples, one field blank (CS-1) was used to verify the sampling protocol. An ocean-water sample (CS-2) was collected from the south side of East Point peninsula in July 1997, and a rainwater sample (CS-3) was collected from a holding tank on a property located along the south shore of East Point (there had been no precipitation in over 1 month on the island).

\section{Data analysis}

Samples were sent for chemical analysis to CanTest ${ }$, where metals were measured using an induced coupled plasma - mass spectrometer (ICP-MS). Total alkalinity (as $\mathrm{CaCO}_{3}$ ) was measured by potentiometric titration with sulphuric acid to a final $\mathrm{pH}$ of 4.5. Chloride, fluoride, nitrate, and sulphate were measured by ion chromatography, and phosphate was measured using colorimetric procedures on orthophosphate. Metal samples tested in 1997 were analysed with lower precision. Raw chemical data were processed using SOLMINEQ ${ }^{\circledR}$ (Alberta Research Council 1988), a solution and mineral equilibria software program that among other things calculates charge-balance error, speciation, and mineral-saturation indices. The software was also used to adjust for field-determined $\mathrm{pH}$ and to calculate carbonate speciation. Of the 106 samples analyzed, 41 samples had charge-balance errors of $<5 \%$, and 93 samples had chargebalance errors of $<15 \%$. Charge-balance errors tended to favour the anions (more negative than positive errors were calculated), which perhaps may be explained by the presence of dissolved silica $\left(\mathrm{SiO}_{2}\right)$ that is not accounted for in the charge balance. Eleven samples had charge-balance errors in excess of $15 \%$ and were discarded. Of the 106 samples collected, 95 were considered for investigation.

\section{Groundwater evolution}

\section{General trends}

Major ions for all samples (Table 2) were plotted on a
Piper plot in an attempt to illustrate trends in water composition (Fig. 5). Rainwater (CS-3) and ocean-water (CS-2) samples, as well as representative samples of salt springs from Nanaimo and Saltspring Island, were also included. Sample CS-2 has all the typical chemical characteristics of seawater and is similar to the ocean-water sample collected by Dakin et al. (1983).

Two main hydrochemical processes act to modify groundwater composition from shallow to deeper regimes. These two processes are best illustrated on the Piper plot (Fig. 5). The first process is a $\mathrm{Ca}^{2+} / \mathrm{Mg}^{2+}$ to $\mathrm{Na}^{+}$shift, which could be explained by cation exchange processes (discussed later in the paper). This shift is clearly evident in the cation triangle. The second is salinization, associated with an increase in $\mathrm{Cl}^{-}$concentration, which is evident in the anion triangle. The overall evolution of groundwater as exhibited in the diamond is from left centre to the bottom left corner, and then to the right corner near the ocean-water point as illustrated by the arrows in Fig. 5. However, there are deviations from this general evolutionary pathway that include, for example, bypassing the cation shift with direct salinization. In the following sections of this paper, we will attempt to describe the nature of the evolution of groundwater and to propose possible mechanisms, in the context of the geological history and hydrogeological setting, for both the general evolution and deviations from it.

To facilitate the description of the evolutionary trend of groundwater, the island was subdivided into seven major flow regions on the basis of topography and likely catchment area (Fig. 2). Two smaller areas (East Point and Winter Cove) were distinguished as subregions on the basis of increased data density and variable topographic expression. Piper diagrams for the Winter Cove and East Point subregions are presented here (Figs. $6 a, 6 b$ ), as these will serve to illustrate the nature of hydrochemical evolution in these areas (discussed later in the paper).

\section{Geochemical characteristics of water}

\section{Rainwater}

Rainwater typically contains low concentrations ( $<1 \mathrm{mg} / \mathrm{L})$ of bicarbonate $\left(\mathrm{HCO}_{3}^{-}\right)$and other forms of dissolved inorganic carbon (Richter and Kreitler 1993). The rainwater control sample, CS-3, contains $9.6 \mathrm{mg} / \mathrm{L} \mathrm{HCO}_{3}{ }^{-}$. Although elevated, this concentration is significantly lower than that of the rainwater sample collected on Mayne Island, which was several hundred milligrams per litre $\mathrm{HCO}_{3}^{-}$(Dakin et al. 1983). Our rain sample contains $25.8 \mathrm{mg} / \mathrm{L} \mathrm{Cl}^{-}, 5.4 \mathrm{mg} / \mathrm{L}$ $\mathrm{SO}_{4}{ }^{2-}$, and $10.0 \mathrm{mg} / \mathrm{L} \mathrm{Na}^{+}$, whereas the weather station situated at high elevation and remote from the coast on Saturna Island reports average concentrations for rainwater of $1.21 \mathrm{mg} / \mathrm{L} \mathrm{Cl}^{-}, 0.68 \mathrm{mg} / \mathrm{L} \mathrm{SO}_{4}{ }^{2-}$, and $0.67 \mathrm{mg} / \mathrm{L} \mathrm{Na}^{+}$(Canadian Air and Precipitation Monitoring Network 2000). The composition of rainwater collected on the Gulf Islands, particularly along the coast, suggests that ocean spray may be a source of elevated concentrations of dissolved constituents. Also, strong winds may contain dust particles that dissolve and become incorporated in precipitation. Therefore, it is unlikely that a single rainwater sample will represent the diverse composition of recharge for different locations on the islands. 
Table 2. Major ion composition of waters on Saturna Island.

\begin{tabular}{|c|c|c|c|c|c|c|c|c|}
\hline Sample No. & Source & $\begin{array}{l}\text { Depth } \\
\text { (m) }\end{array}$ & $\begin{array}{l}\text { Conductivity } \\
(\mu \mathrm{S} / \mathrm{cm})\end{array}$ & $\mathrm{pH}$ & $\begin{array}{l}\text { Temp. } \\
\left({ }^{\circ} \mathrm{C}\right)\end{array}$ & $\begin{array}{l}P_{\mathrm{CO}_{2}} \\
\text { (atm) }\end{array}$ & $\begin{array}{l}\mathrm{HCO}_{3}^{-} \\
(\mathrm{mg} / \mathrm{L})\end{array}$ & $\begin{array}{l}\mathrm{Cl} \\
(\mathrm{mg} / \mathrm{L})\end{array}$ \\
\hline BB-1 & Spring & & 247 & 6.81 & 12.7 & -1.69 & 141.4 & 10.0 \\
\hline BB-2 & Spring & & 141 & 6.50 & 12.3 & -1.75 & 60.2 & 14.5 \\
\hline BB-3 & GW & & 301 & 7.58 & 14.9 & -2.34 & 185.9 & 12.6 \\
\hline BB-4 & GW & & 429 & 7.82 & 15.7 & -2.45 & 253.0 & 12.2 \\
\hline BB-5 & GW & 244 & 409 & 8.06 & 15.6 & -2.65 & 279.7 & 26.4 \\
\hline BR-S & Swamp & & 137 & 7.49 & 12.3 & -2.77 & 56.2 & 7.1 \\
\hline $\mathrm{CS}-2$ & Ocean & & 32800 & 7.80 & 16.0 & -2.65 & 248.1 & 18400.0 \\
\hline CS-3 & Rain & & 208 & 5.84 & 16.7 & -1.79 & 11.6 & 25.8 \\
\hline EP-1 & GW & & 588 & 7.66 & 15.0 & -2.43 & 188.0 & 96.6 \\
\hline EP-2 & GW & 81 & 1307 & 8.19 & 15.2 & -3.11 & 135.8 & 332.0 \\
\hline EP-3 & GW & 85 & 916 & 8.35 & 14.7 & -3.42 & 94.4 & 209.0 \\
\hline EP-7 & GW & & 485 & 8.50 & 12.0 & -3.29 & 178.5 & 50.4 \\
\hline EP-8 & GW & & 390 & 8.64 & 17.2 & -3.32 & 220.6 & 11.2 \\
\hline EP-9 & GW & & 357 & 8.35 & 19.0 & -3.04 & 211.0 & 10.5 \\
\hline EP-10 & GW & & 353 & 7.26 & 21.8 & -2.02 & 178.0 & 17.3 \\
\hline EP-11 & Spring & & 175 & 6.76 & 18.3 & -2.09 & 48.2 & 14.5 \\
\hline EP-12 & GW & & 400 & 8.01 & 17.3 & -2.78 & 179.4 & 39.9 \\
\hline EP-13 & GW & & 198 & 6.19 & 15.2 & -1.46 & 57.3 & 15.8 \\
\hline EP-14 & Spring & & 182 & 6.34 & 17.5 & -1.43 & 85.7 & 16.5 \\
\hline EP-15 & GW & & 325 & 7.67 & 12.2 & -2.43 & 188.3 & 14.1 \\
\hline EP-16 & GW & & 406 & 8.01 & 19.1 & -2.73 & 199.5 & 25.8 \\
\hline EP-17 & GW & 67 & 781 & 7.58 & 14.1 & -2.26 & 230.2 & 126.0 \\
\hline EP-18 & GW & & 841 & 8.07 & 17.1 & -2.86 & 175.7 & 180.0 \\
\hline EP-27C & GW & 110 & 4010 & 7.80 & 13.5 & -2.75 & 142.7 & 1530.0 \\
\hline EP-28B & GW & 152 & 1440 & 7.60 & 14.0 & -2.64 & 104.9 & 439.0 \\
\hline EP-29B & GW & 68 & 968 & 8.30 & 12.5 & -3.28 & 117.6 & 258.0 \\
\hline EP-29C & GW & 68 & 3310 & 8.10 & 13.5 & -3.27 & 82.0 & 1180.0 \\
\hline EP-30 & $\mathrm{GW}$ & 91 & 310 & 7.30 & 12.6 & -2.14 & 157.7 & 12.2 \\
\hline EP-31 & GW & 122 & 250 & 7.92 & 13.2 & -2.84 & 131.3 & 12.7 \\
\hline EP-32 & GW & 151 & 540 & 9.43 & 11.3 & -4.43 & 110.9 & 116.0 \\
\hline EP-S & Swamp & & 324 & 6.60 & 19.0 & -1.88 & 55.9 & 62.7 \\
\hline LC-1 & GW & 40 & 569 & 7.16 & 16.2 & -1.67 & 347.7 & 18.4 \\
\hline LC-2 & GW & 44 & 2220 & 8.93 & 16.1 & -3.48 & 333.5 & 161.0 \\
\hline LC-3 & Creek & & 148 & 7.70 & 17.0 & -2.97 & 56.1 & 9.8 \\
\hline LC-4 & GW & 61 & 941 & 7.85 & 17.6 & -2.43 & 290.6 & 101.0 \\
\hline LC-5 & GW & 49 & 396 & 7.96 & 16.3 & -2.65 & 224.1 & 12.6 \\
\hline LC-6 & GW & 49 & 275 & 6.57 & 12.3 & -1.44 & 147.4 & 14.0 \\
\hline LC-7 & GW & & 460 & 8.93 & 18.1 & -3.53 & 266.9 & 9.8 \\
\hline LC-8 & GW & 61 & 1054 & 9.23 & 11.6 & -3.75 & 344.8 & 32.7 \\
\hline MD-1 & GW & & 397 & 7.61 & 14.6 & -2.27 & 234.0 & 23.8 \\
\hline MD-2 & GW & & 7.41 & 8.05 & 13.5 & -3.14 & 108.3 & 2800.0 \\
\hline MD-3 & GW & & 411 & 9.24 & 13.0 & -3.99 & 193.6 & 13.8 \\
\hline MD-4 & GW & & 412 & 7.18 & 11.7 & -1.89 & 214.0 & 16.1 \\
\hline MD-5 & GW & 5 & 445 & 9.36 & 12.4 & -4.11 & 192.3 & 16.5 \\
\hline
\end{tabular}




\begin{tabular}{|c|c|c|c|c|c|c|c|c|}
\hline $\begin{array}{l}\mathrm{SO}_{4} \\
(\mathrm{mg} / \mathrm{L})\end{array}$ & $\begin{array}{l}\mathrm{Ca} \\
(\mathrm{mg} / \mathrm{L})\end{array}$ & $\begin{array}{l}\mathrm{Mg} \\
(\mathrm{mg} / \mathrm{L})\end{array}$ & $\begin{array}{l}\mathrm{SiO}_{2} \\
(\mathrm{mg} / \mathrm{L})\end{array}$ & $\begin{array}{l}\mathrm{Na} \\
(\mathrm{mg} / \mathrm{L})\end{array}$ & $\begin{array}{l}\mathrm{K} \\
(\mathrm{mg} / \mathrm{L})\end{array}$ & $\mathrm{SI}_{\mathrm{cal}}$ & $\mathrm{SI}_{\mathrm{dol}}$ & $\mathrm{SI}_{\mathrm{gyp}}$ \\
\hline 21.8 & 24.30 & 4.40 & 9.15 & 18.80 & 0.53 & -1.236 & -1.977 & -2.541 \\
\hline 15.2 & 13.70 & 3.14 & 9.17 & 8.36 & 0.76 & -2.135 & -3.676 & -2.877 \\
\hline 19.4 & 37.30 & 2.24 & 8.69 & 24.60 & 0.51 & -0.147 & -0.265 & -2.449 \\
\hline 25.4 & 21.40 & 4.08 & 8.70 & 55.70 & 0.26 & -0.016 & 0.503 & -2.585 \\
\hline 16.2 & 14.30 & 3.65 & 10.80 & 89.90 & 0.27 & 0.081 & 0.826 & -2.968 \\
\hline 32.2 & 8.20 & & 6.50 & 57.80 & 0.12 & 0.195 & & -2.857 \\
\hline 32.9 & 4.84 & 0.78 & 12.00 & 88.70 & 0.62 & 0.273 & 1.007 & -3.111 \\
\hline 4.0 & 10.60 & 2.39 & 9.67 & 7.09 & 0.31 & & & \\
\hline 2150.0 & 385.00 & 996.00 & 3.20 & 8530.00 & 362.00 & & & \\
\hline 5.4 & 4.29 & 1.80 & 0.84 & 10.00 & 1.65 & & & \\
\hline 25.9 & 25.70 & 2.87 & 10.50 & 78.40 & 0.52 & -0.246 & -0.192 & -2.520 \\
\hline 33.8 & 47.20 & 5.65 & 8.67 & 246.00 & 0.91 & 0.338 & 1.013 & -2.289 \\
\hline 48.0 & 22.80 & 0.65 & 8.42 & 181.00 & 0.29 & 0.051 & -0.191 & -2.366 \\
\hline 31.7 & 21.00 & 3.84 & 9.29 & 106.00 & 0.71 & 0.290 & 1.095 & -2.547 \\
\hline 21.8 & 16.10 & 1.35 & 9.28 & 119.00 & 0.40 & 0.058 & 0.298 & -2.812 \\
\hline 65.6 & 282.00 & 40.80 & 14.30 & 974.00 & 7.04 & -0.295 & -0.158 & -1.654 \\
\hline 34.5 & 16.20 & 1.48 & 12.90 & 95.00 & 0.80 & 0.317 & 0.833 & -2.982 \\
\hline 20.3 & 9.88 & 1.20 & 10.60 & 65.30 & 0.34 & 0.423 & 1.203 & -3.362 \\
\hline 18.9 & 5.87 & 0.53 & 8.94 & 54.30 & 0.24 & -0.063 & 0.109 & -3.569 \\
\hline 24.3 & 28.20 & 2.24 & 11.50 & 41.90 & 0.40 & -0.505 & -0.816 & -2.469 \\
\hline 18.9 & 12.80 & 3.60 & 13.90 & 12.00 & 0.70 & -1.911 & -3.105 & -2.824 \\
\hline 16.6 & 21.20 & 1.12 & 9.57 & 53.20 & 0.36 & 0.059 & 0.106 & -2.750 \\
\hline 15.0 & 15.20 & 3.84 & 14.90 & 11.50 & 0.64 & -2.381 & -4.110 & -2.855 \\
\hline 4.7 & 15.80 & 2.98 & 13.10 & 7.76 & 1.06 & -1.999 & -3.498 & -3.336 \\
\hline 13.0 & 25.60 & 1.92 & 9.71 & 36.40 & 0.36 & -0.246 & -0.382 & -2.754 \\
\hline 18.1 & 17.00 & 0.65 & 9.14 & 60.60 & 0.31 & 0.034 & -0.072 & -2.807 \\
\hline 34.8 & 19.90 & 0.96 & 11.90 & 108.00 & 0.43 & -0.378 & -0.827 & -2.521 \\
\hline 18.2 & 11.10 & & 8.11 & 132.00 & 0.19 & -0.211 & & -3.051 \\
\hline 23.2 & 25.00 & 4.42 & 10.80 & 45.00 & 0.68 & -0.863 & -1.236 & -2.544 \\
\hline 29.4 & 39.10 & 2.87 & 8.29 & 220.00 & 0.86 & 0.280 & 0.696 & -2.401 \\
\hline 16.8 & 31.70 & 2.98 & 8.68 & 107.00 & 0.73 & 0.195 & & -2.647 \\
\hline 12.2 & 10.90 & 0.72 & 9.82 & 41.70 & 0.28 & -0.463 & -0.858 & -3.119 \\
\hline 13.2 & 15.20 & 1.19 & 8.97 & 54.60 & 0.35 & 0.112 & 0.372 & -2.981 \\
\hline 15.5 & 19.30 & 1.91 & 8.86 & 54.00 & 0.52 & 0.072 & 0.382 & -2.813 \\
\hline 16.5 & 22.90 & 4.06 & 15.80 & 62.50 & 0.58 & -0.255 & -0.019 & -2.727 \\
\hline 209.0 & 193.00 & 51.10 & 17.70 & 722.00 & 4.28 & 0.376 & 1.438 & -1.253 \\
\hline 53.8 & 26.10 & 1.03 & 12.20 & 278.00 & 0.60 & -0.643 & -1.439 & -2.336 \\
\hline 34.4 & 10.30 & 0.84 & 14.20 & 204.00 & 1.21 & -0.282 & -0.412 & -2.849 \\
\hline 184.0 & 212.00 & 41.80 & 14.40 & 648.00 & 1.81 & 0.597 & 1.749 & -1.236 \\
\hline 24.5 & 31.20 & 3.76 & 15.30 & 46.20 & 0.61 & -0.612 & -0.905 & -2.418 \\
\hline 25.5 & 25.90 & 3.26 & 14.10 & 33.60 & 0.17 & -0.131 & 0.077 & -2.460 \\
\hline 1.5 & 2.91 & 0.11 & 10.10 & 134.00 & 0.37 & 0.250 & 0.332 & -4.716 \\
\hline 27.8 & 13.30 & 7.39 & 25.90 & 47.20 & 1.43 & -2.022 & -3.025 & -2.720 \\
\hline 40.4 & 90.70 & 13.80 & 10.70 & 13.80 & 1.43 & 0.043 & 0.528 & -2.256 \\
\hline 671.0 & 11.60 & 0.81 & 5.00 & 574.00 & 1.02 & 0.644 & 1.391 & -2.252 \\
\hline 14.7 & 11.70 & 3.54 & 18.00 & 16.30 & 0.68 & -0.963 & -1.186 & -3.333 \\
\hline 124.0 & 38.30 & 8.65 & 11.50 & 167.00 & 2.21 & 0.260 & 1.139 & -2.165 \\
\hline 27.3 & 31.60 & 6.66 & 20.00 & 65.70 & 5.74 & 0.240 & 1.062 & -2.781 \\
\hline 13.8 & 36.00 & 9.86 & 20.20 & 19.40 & 1.32 & -1.306 & -1.938 & -3.010 \\
\hline 20.5 & 3.61 & 0.78 & 12.50 & 108.00 & 0.24 & 0.322 & 1.270 & -3.849 \\
\hline 178.0 & 3.40 & 0.40 & 8.24 & 253.00 & 0.90 & 0.462 & 1.252 & -3.189 \\
\hline 13.0 & 1.52 & 0.20 & 11.80 & 113.00 & 0.56 & -1.413 & -2.458 & -4.373 \\
\hline 5.3 & 181.00 & 10.10 & 6.26 & 1440.00 & 2.64 & 0.450 & 0.926 & -3.346 \\
\hline 13.5 & 10.60 & 2.25 & 9.34 & 56.60 & 1.06 & 0.893 & 1.307 & -3.571 \\
\hline 20.6 & 41.20 & 8.10 & 8.54 & 16.60 & 0.96 & -0.500 & -0.473 & -2.801 \\
\hline 19.1 & 3.04 & 0.50 & 7.38 & 103.00 & 0.25 & 0.427 & 1.337 & -4.011 \\
\hline
\end{tabular}


Table 2 (concluded).

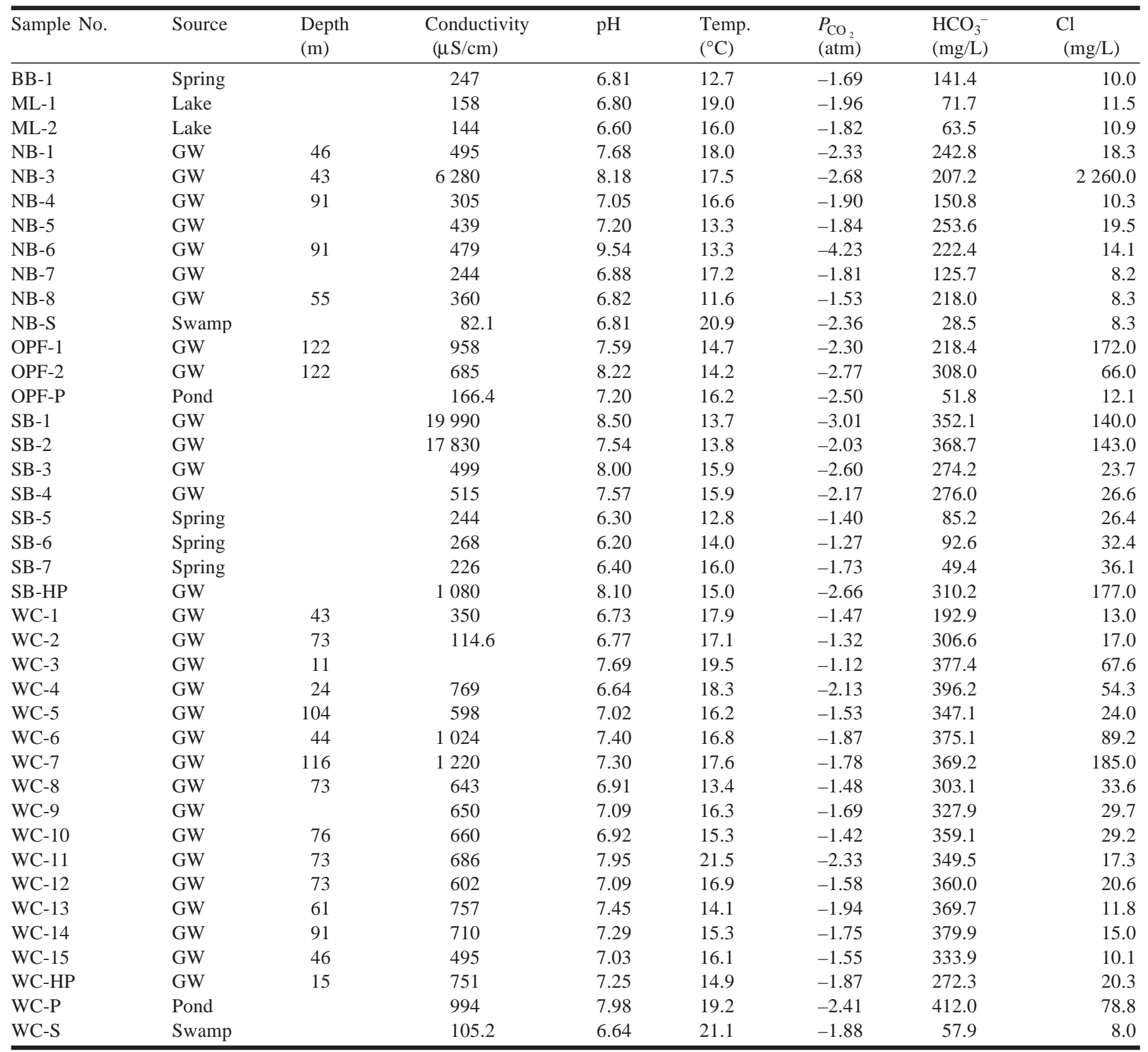

Note: $\mathrm{HCO}_{3}$ concentration, $P_{\mathrm{CO}_{2}}$, and SI values calculated using SOLMINEQ (Alberta Research Council 1988). $\mathrm{SI}_{\text {cal }}$, $\mathrm{SI}_{\mathrm{dol}}$, and $\mathrm{SI}_{\text {gyp }}$ are saturation indices with respect to calcite, dolomite, and gypsum, respectively.

\section{Surface waters and spring waters}

The surface-water samples consist of Lyall Creek (LC-3), Money Lake (ML-2), and six swamp specimens (WC-P, WC-S, NB-S, BR-S, EP-S, and OPF-P). In most surface-water samples, $\mathrm{HCO}_{3}{ }^{-}$is the major anion and $\mathrm{Cl}^{-}$is the second most abundant, and $\mathrm{Ca}^{2+}$ and $\mathrm{Na}^{+}$are the major cations. Lyall Creek receives surface runoff and possibly groundwater discharge along a valley in the Lyall Harbour flow region (Fig. 2). Money Lake (Fig. 2) is man-made and receives primarily surface runoff. Most swamps are situated at high elevation and likely represent the composition of precipitation and local shallow groundwater. EC values for these swamp waters are all below $166 \mu \mathrm{S} / \mathrm{cm}, \mathrm{HCO}_{3}{ }^{-}$values are all below
$52.5 \mathrm{mg} / \mathrm{L}$, and $\mathrm{pH}$ falls between 6.5 and 7.5. Pond-water sample WC-P, although appearing similar to other surfacewater samples (Fig. 5), has a high EC (994 $\mu \mathrm{S} / \mathrm{cm})$ and resembles the composition of groundwater from the Winter Cove area (Fig. 7b). Its chemical character suggests that this pond may originate as a groundwater seep. The chemical composition of sample EP-S is also distinct from those of the other swamp samples and plots close to the composition of other East Point groundwaters (Fig. 5). Its high EC (324 $\mu \mathrm{S} / \mathrm{cm})$ suggests that this swamp also may be a groundwater seep associated with discharge (Figs. 7a, 7b). Alternatively, the swamp may be a local recharge area for waters on East Point, but it may be more saline due to ocean spray. 


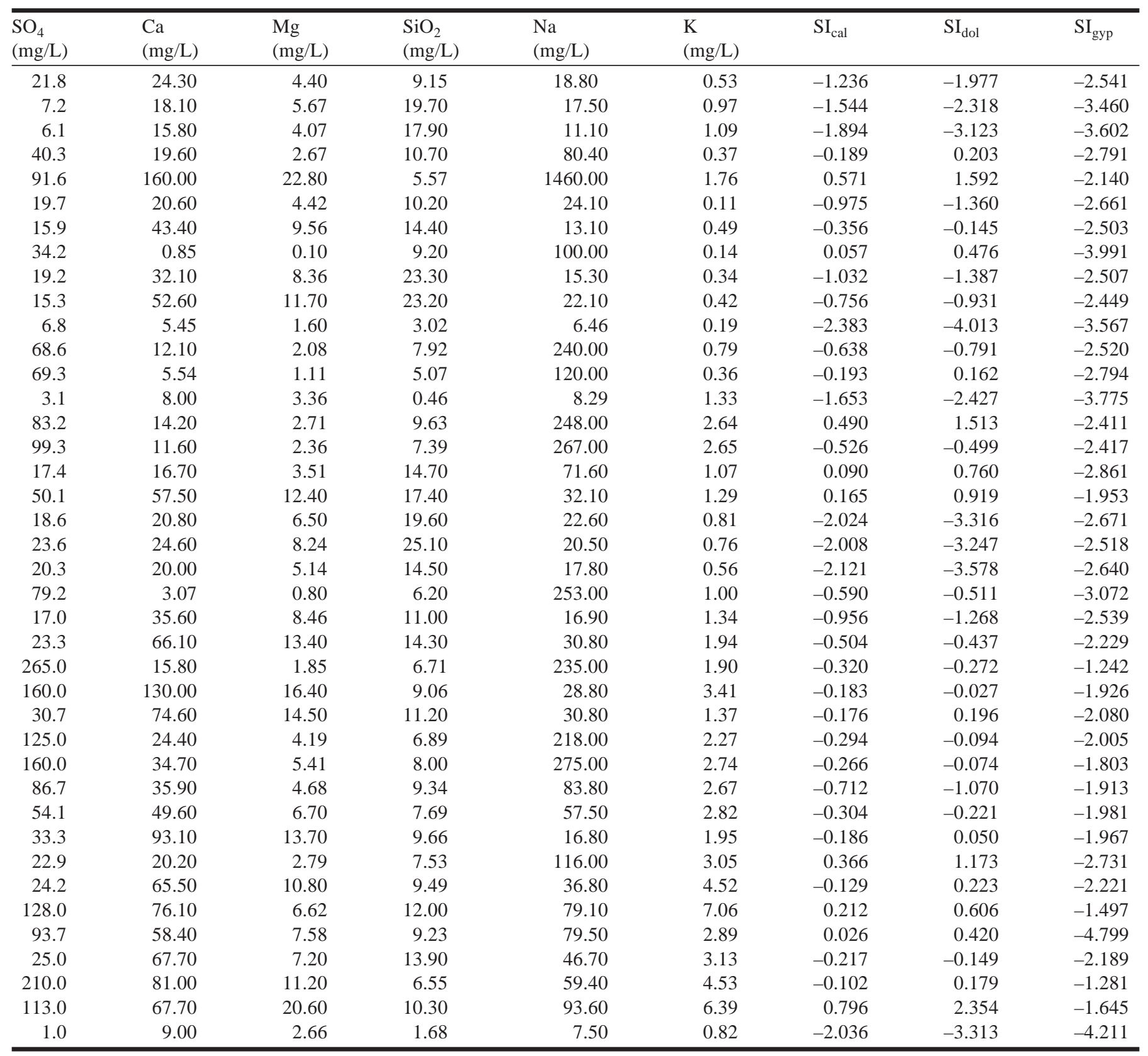

Of the eight spring-water samples, six have a chemical composition similar to those of the surface waters and all tend to plot in a cluster on the Piper plot (Fig. 5). These samples have EC values between 141 and $460 \mu \mathrm{S} / \mathrm{cm}$ and a range of $\mathrm{pH}$ values between 6.2 and $6.8 . \mathrm{HCO}_{3}{ }^{-}$is the dominant anion in all spring samples. In half the samples, $\mathrm{Cl}^{-}$is the second dominant anion, whereas in the other half $\mathrm{SO}_{4}{ }^{2-}$ is the second dominant anion. The major cations are $\mathrm{Ca}^{2+}$ and $\mathrm{Na}^{+}$. Dissolved $\mathrm{SiO}_{2}$ is typically less than $10 \mathrm{mg} / \mathrm{L}$.

The low EC of most spring waters and the low $\mathrm{Na} /(\mathrm{Ca}+\mathrm{Mg})$ molar ratio suggest that the springs have a chemically immature composition compared with most groundwaters. Figure $7 a$ illustrates this point by showing the trend of chemical evolu- tion. In addition, most springs have a $\mathrm{Cl} / \mathrm{HCO}_{3}{ }^{-}$molar ratio of less than one (Fig. 7b), suggesting a shallow source or certainly no contact with deep saline waters. LC-7 has an exceptionally high $\mathrm{Na} /(\mathrm{Ca}+\mathrm{Mg}$ ) molar ratio (Fig. $7 a)$, suggesting that this water has undergone cation shift. However, the low $\mathrm{Cl} / \mathrm{HCO}_{3}{ }^{-}$molar ratio (Fig. $7 b$ ) suggests that cation shift may be accompanied by mineral dissolution (perhaps calcite, dolomite, or feldspar) producing $\mathrm{HCO}_{3}^{-}$.

Figure 8 shows bicarbonate versus $\mathrm{pH}$ for all water samples and illustrates both open- and closed-system paths for the dissolution of carbonate minerals (calcite and dolomite) in initially ion-free water (Freeze and Cherry 1979). Most surfaceand spring-water samples plot relatively close together at a 
Fig. 5. Piper diagram representing all samples collected for this study (data for Saltspring Island and Nanaimo springs from Dakin et al. 1983).

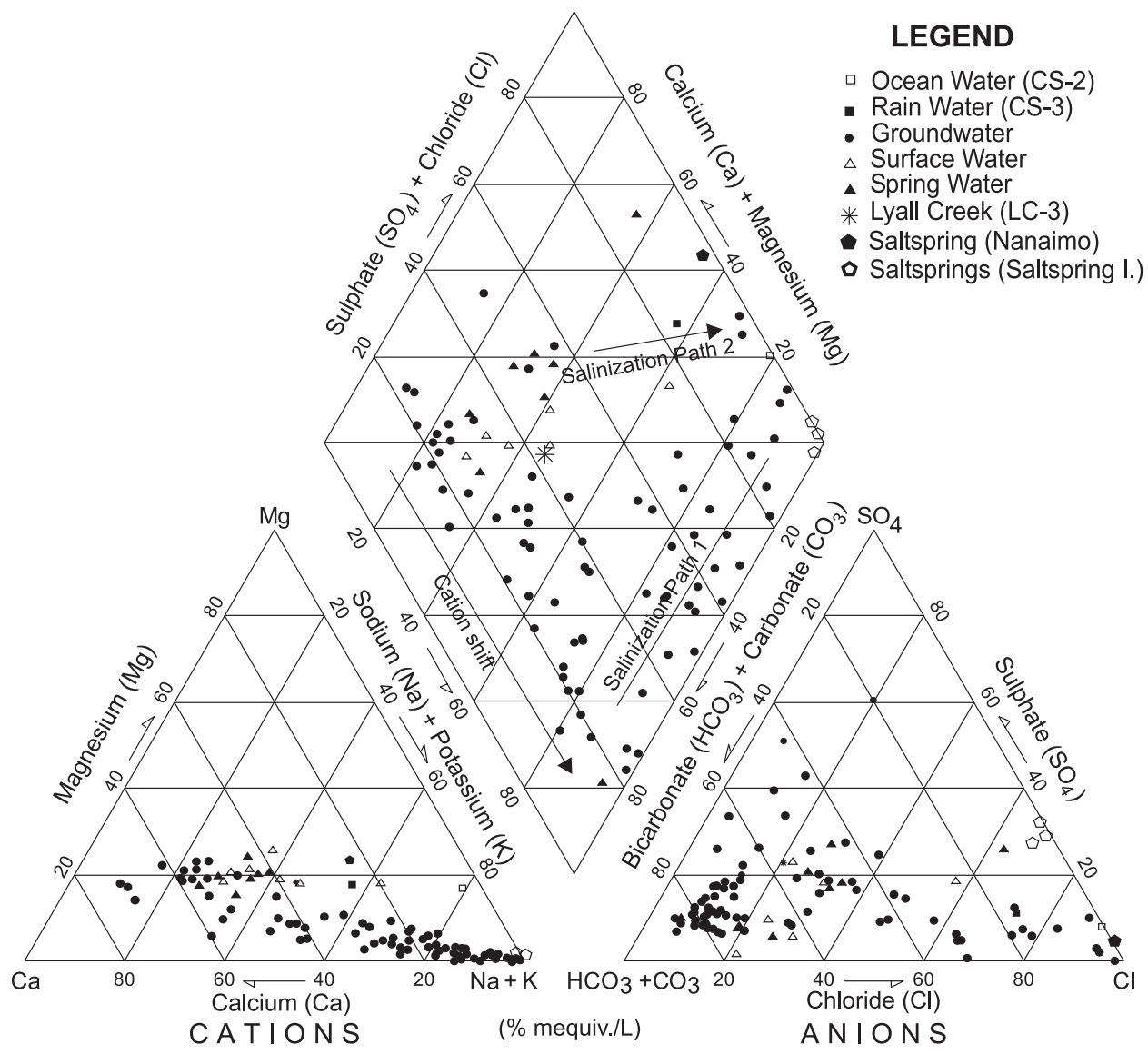

$\mathrm{pH}$ of slightly less than 7.0 and $\mathrm{HCO}_{3}^{-}$concentration of about $10^{-3} \mathrm{~mol} / \mathrm{L}$. The spring waters have moderate $\mathrm{CO}_{2}$ partial pressure $\left(P_{\mathrm{CO}}\right.$ rarely exceeds $10^{-2}$ atm $(1 \mathrm{~atm}=$ $101.325 \mathrm{kPa})$ ). Sample LC-7 is shown to be distinctly different from other spring samples and resembles groundwaters $(\mathrm{GW})$ with high cation molar ratio (CMR; GW: CMR > 20 in Fig. 8). CMR is defined as the ratio $\mathrm{Na} /(\mathrm{Ca}+\mathrm{Mg})$. It is likely that this spring water evolved along a pathway under closed-system conditions (i.e., depletion of $\mathrm{CO}_{2}$ ). This interpretation is consistent with the associated mineral dissolution described earlier in the paper.

\section{Groundwater}

Groundwater on Saturna Island has both a wide variation in composition and a wide range of salinity, reflecting the variable composition of recharge and discharge waters in the flow system. Groundwater samples range in conductivity from 114 to $6280 \mu \mathrm{S} / \mathrm{cm}$. $\mathrm{HCO}_{3}{ }^{-}$, which in the groundwater samples accounts for approximately $94 \%$ of total alkalinity, ranges from a low of $57 \mathrm{mg} / \mathrm{L}$ to a high of $396 \mathrm{mg} / \mathrm{L}$. Of the eight groundwater samples with $\mathrm{HCO}_{3}{ }^{-}$less than $100 \mathrm{mg} / \mathrm{L}$, five are located near recharge zones. Samples from East Point have $\mathrm{HCO}_{3}{ }^{-}$in the hundreds of milligrams per litre range, and those from Lyall Harbour and Winter Cove are typically above $300 \mathrm{mg} / \mathrm{L}$. $\mathrm{Cl}^{-}$is the most variable anion, ranging from 8.3 to $2800 \mathrm{mg} / \mathrm{L}$, and is the dominant anion when EC is high. Samples with moderate EC levels have $\mathrm{HCO}_{3}{ }^{-}$as the dominant anion, especially in the Winter Cove region. $\mathrm{SO}_{4}{ }^{2-}$ concentrations vary between 1.5 and $671 \mathrm{mg} / \mathrm{L}$; however, only eight samples have concentrations above $124 \mathrm{mg} / \mathrm{L}$ and only one exceeded $265 \mathrm{mg} / \mathrm{L}$. Most samples have sulphate concentrations between 15 and $40 \mathrm{mg} / \mathrm{L} . \mathrm{Na}^{+}$is the dominant cation when EC is very high. Of the 15 samples in which $\mathrm{EC}$ is low, $\mathrm{Ca}^{2+}$ is the dominant cation and $\mathrm{HCO}_{3}^{-}$is the dominant anion.

Groundwater with a low EC typically plots in the leftcentre portion of the diamond on the Piper plot (Fig. 5), reflecting a $\mathrm{Ca}-\mathrm{HCO}_{3}$ composition. Figure $7 b$ shows a dominant cluster of groundwater samples at low $\mathrm{Cl} / \mathrm{HCO}_{3}$ ratios for $\mathrm{EC}<1000 \mu \mathrm{S} / \mathrm{cm}$ just below and to the right of the surface- and spring-water samples, suggesting that most fresh groundwaters are recharged locally and gain $\mathrm{HCO}_{3}{ }^{-}$ while dissolving minerals in the shallow subsurface. As EC increases, $\mathrm{Cl} / \mathrm{HCO}_{3}$ ratios increase and reflect a gain of $\mathrm{Cl}^{-}$ rather than a loss of $\mathrm{HCO}_{3}{ }^{-}$. The high $\mathrm{EC}$ values reflect more mature groundwaters that are located deeper in the flow system or in a discharge area.

\section{Cation exchange}

Figure 5 shows that many groundwaters have evolved along pathways resulting in a $\mathrm{Ca}^{2+} / \mathrm{Mg}^{2+}$ to $\mathrm{Na}^{+}$shift. We believe that this shift is likely the result of cation exchange. Figure 8 shows groundwater samples categorized on the basis of their CMR. Groundwater samples with a CMR > 20 typically plot above the calcite and dolomite saturation lines. Several groundwater samples with $20>\mathrm{CMR}>3$ plot above these 
Fig. 6. Piper diagrams for samples from (a) East Point subregion, and (b) Winter Cove subregion.

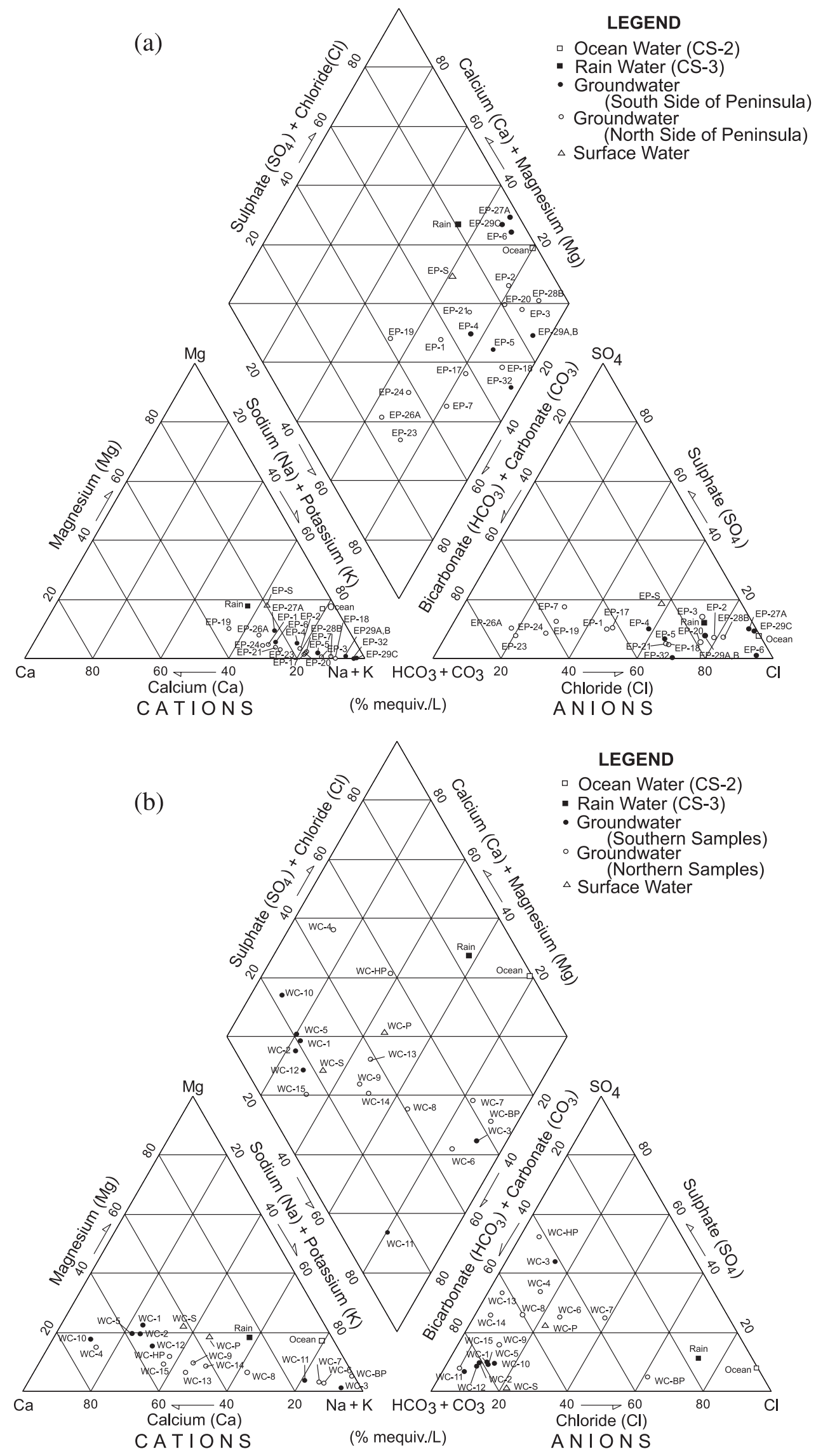


Fig. 7. (a) $\mathrm{Na} /\left(\mathrm{Ca}+\mathrm{Mg}\right.$ ) versus electrical conductivity (EC). (b) $\mathrm{Cl} / \mathrm{HCO}_{3}$ versus electrical conductivity (EC).
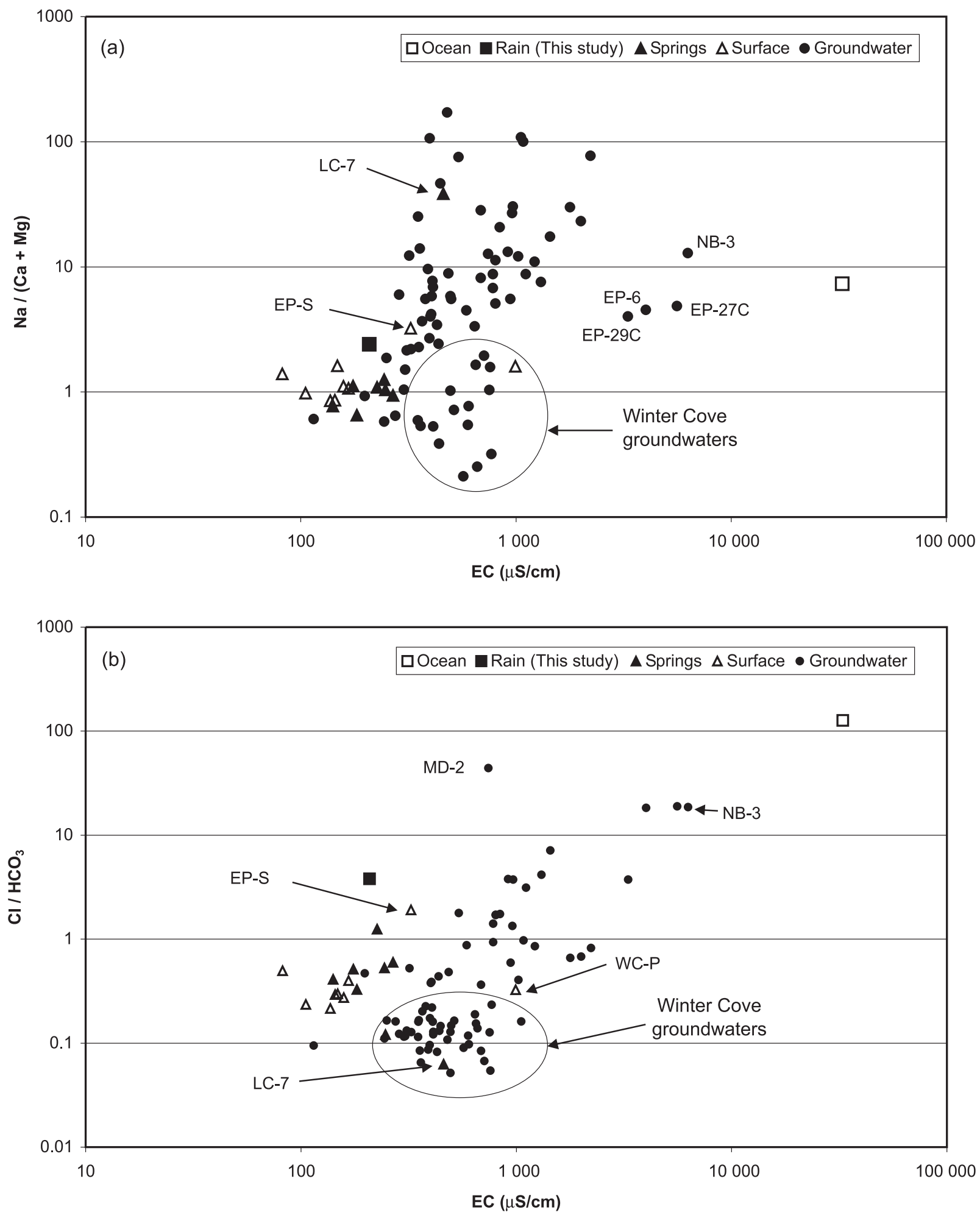

lines as well. Figure $7 a$ shows that there is not a strong relation between the CMR and the EC, which suggests that cation exchange is likely independent of salinity increases in most samples. Groundwater samples with $20>\mathrm{CMR}>3$ plot close to the calcite and dolomite saturation lines (Fig. 8), suggesting that cation exchange is occurring while likely dissolving calcite and dolomite under closed-system conditions (i.e., at the expense of $\mathrm{CO}_{2}$ ). For groundwater samples with a $3>\mathrm{CMR}>1$, we observe that most plot below saturation with respect to calcite and dolomite. This trend suggests that $\mathrm{Ca}^{2+}$ and $\mathrm{Mg}^{2+}$ are not replaced by dissolution of carbonate minerals (i.e., these minerals 
Fig. 8. Bicarbonate versus pH. Cation molecular ratio (CMR) for groundwaters $(\mathrm{GW})$ is defined as $\mathrm{Na} /(\mathrm{Ca}+\mathrm{Mg})$.

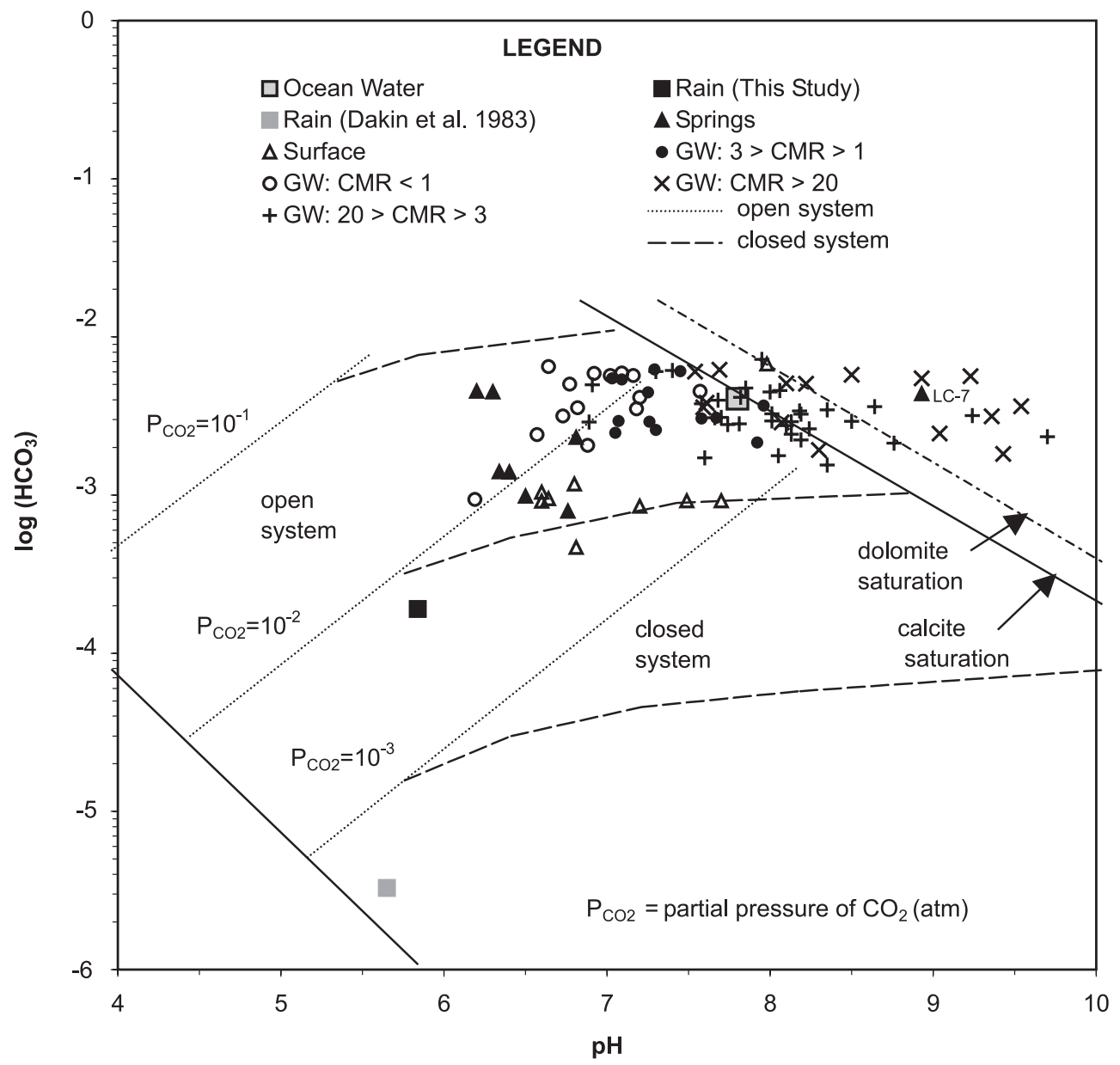

remain undersaturated) while cation exchange occurs. Finally, for groundwater samples with a CMR $<1$, we observe undersaturation with respect to calcite and dolomite. These low-CMR groundwaters also plot beneath and to the right of the spring- and surface-water samples in Fig. $7 a$. Many of these low-ratio samples were collected in the Winter Cove subregion, and most notably from wells completed in the de Courcy Formation (Fig. 3). This formation is described as a relatively clean sandstone (Table 1), and therefore likely does not host many exchange sites.

The overall evolution of groundwater can be described using Fig. 8. Springs represent the initial composition of recharging, which eventually becomes deep groundwater after geochemical evolution. The initial water has a $\mathrm{P}_{\mathrm{CO}_{2}}$ in the range of $10^{-1.5}$ to $10^{-2.5}$ atm, perhaps as a result of $\mathrm{CO}_{2}$ equilibration in the soil zone and subsequent dissolution of carbonate minerals under "open" system conditions. The initial water enters the intermediate to deep aquifer and dissolves more carbonate minerals under closed conditions and simultaneously exchanges $\mathrm{Ca}^{2+}$ and $\mathrm{Mg}^{2+}$ with $\mathrm{Na}^{+}$, such that the water remains at or slightly above saturation with respect to the carbonate minerals. It is important to note that the effect of ionic strength is not taken into account in Fig. 8. Table 2 provides the saturation indices (SI) for calcite, dolomite, and gypsum. SI is defined as the $\log \left(\mathrm{IAP} / \mathrm{K}_{\mathrm{sp}}\right)$, where IAP is defined as the ion activity product and $\mathrm{K}_{\mathrm{sp}}$ is the equilbrium solubility product. Most groundwater samples are at or close to saturation with respect to calcite and dolomite, and undersaturated with respect to gypsum.

\section{Salinization}

The second dominant hydrochemical process on Saturna Island is salinization accompanied by an increase in EC. Salinization is typically associated with an increase in $\mathrm{Cl}^{-}$, although in some areas, specifically Winter Cove, salinization has occurred as a result of increased $\mathrm{SO}_{4}{ }^{2-}$. Two distinct pathways can be identified on the Piper plot (Fig. 5), which are related to salinization. Path 1 is characterized by an increase in $\mathrm{Cl}^{-}$, which typically follows cation exchange. Path 2 is characterized by an increase in $\mathrm{Cl}^{-}$, but without significant cation exchange. In a previous discussion on cation exchange, it was noted that salinization is not directly correlated with cation exchange. The two processes can act independently from the perspective that $(i)$ cation exchange does not require salinization, and (ii) $\mathrm{Na} /(\mathrm{Ca}+\mathrm{Mg})$ molar ratios above 10 show no correlation with EC (Fig. 7a). Notwithstanding this observation, one could argue that there is a slight positive slope to the data within the molar ratio range $1-10$, which may suggest that cation exchange can be accompanied by salinization. 
Most Saturna groundwaters plot along an evolutionary path (Fig. 5) that extends from immature groundwater, through cation exchange, and finally, to high salinity. In fact, the highest EC waters plot to the far right on the Piper diamond, immediately below ocean water. There is also a gradual increase in EC along the bottom edge of the Piper diamond from left to right. Despite this general trend, salinization can occur without cation exchange or with minor cation exchange (path 2 in Fig. 5). To best illustrate these differences we will discuss the results for the East Point flow region.

East Point residents, as well as residents from other areas on Saturna, have experienced notable water quality and quantity degradation in recent years. Residents who previously had no problems with their water supplies have reported increases in turbidity, dry wells, lower yields, and a higher incidence of nitrate and bacterial contamination. Furthermore, there is a higher incidence of abandoned wells on East Point due to high-salinity groundwaters, and many residents have opted to use rainwater collection systems in lieu of groundwater. As more lots become developed, there is a larger demand on groundwater resources. The demand is further compromised in the summer when precipitation is low and water use is high. Because of the low topographic relief and small catchment area, East Point peninsula also tends to receive less precipitation than adjacent flow regions. There are no permanent springs or seeps, and groundwaters have high $\mathrm{Na} /(\mathrm{Ca}+\mathrm{Mg}$ ) ratios (Fig. $6 a)$.

Figure $6 a$ shows the distribution of groundwater samples from the south and north sides of the peninsula. The samples were separated to represent groundwaters collected up and down geological dip of the underlying Geoffrey Formation. Most samples plot in a tight cluster on the cation triangle and exhibit a gradual salinization as evidenced by the increase in $\mathrm{Cl}^{-}$in the anion triangle. Samples EP-27A, EP-29C, and EP-6 all have very high EC (>2000 $\mu \mathrm{S} / \mathrm{cm})$ and a lower percentage of $\mathrm{Na}^{+}$than the other southern samples. These data plot slightly above the ocean-water point on the diamond (Fig. 6a), suggesting that waters from these wells may be directly influenced by seawater.

The relation between distance along the peninsula and $\mathrm{Cl}^{-}$ and $\mathrm{HCO}_{3}{ }^{-}$is illustrated in Figs. $9 a$ and $9 b$. Most samples collected on the south shore show a distinct positive linear trend between the $\mathrm{Cl}^{-} / \mathrm{HCO}_{3}{ }^{-}$molar ratio and distance along East Point (from west to east; Fig. 9a). The presence of low ratios along the south shore is likely related to the occurrence of fractures. North shore ratios display no significant trend in Fig. $9 a$. Because $\mathrm{Cl}^{-}$is present in very high concentrations, it is instructive to plot the inverse ratio $\mathrm{HCO}_{3}{ }^{-} / \mathrm{Cl}^{-}$ in a similar fashion (Fig. 9b). Samples on the southern shore (EP-4, EP-5, EP-6, EP-27, EP-29, and EP-32) generally exhibit little variation in $\mathrm{HCO}_{3}{ }^{-} / \mathrm{Cl}^{-}$with distance (open circles in Fig. 9b), whereas samples from the northern shore (solid circles in Fig. $9 b$ ) tend to exhibit a decrease in this ratio with an increase in distance along the peninsula. These relations suggest not only that the southern shore receives very little recharge, but also that recharge likely occurs from a higher elevation to the west (refer to Fig. 2), and that inflow of fresh groundwater to East Point is restricted to the landward end of the peninsula.

To investigate whether there has been a measurable decline in water quality on East Point, the analyses from sample site EP-27 for 1983, 1986, and 1997 were compared. There is a substantial variation in the conductivity values measured in each of years 1983, 1986, and 1997: 1300, 5500 , and $4010 \mu \mathrm{S} / \mathrm{cm}$, respectively. The significant increase between 1983 and 1986 lends support to the conclusion that salinization is prevalent along the south shore of East Point peninsula, but the subsequent decline between 1986 and 1997 suggests that perhaps seasonal variability associated with precipitation or sampling period may be a major factor controlling salinity.

The absence of fresh groundwaters and springs and the high salinization of groundwater measured in this area are likely a result of the smaller flow region and low local infiltration. The high-elevation area to the west is likely the primary recharge zone for East Point groundwaters. The high EC of the swamp (EP-S) located in the central portion of the peninsula supports the conclusion that East Point is a discharge area. Furthermore, the long surrounding shoreline and finite land mass result in a limited fresh groundwater volume. These conditions suggest that freshwater reserves may be severely compromised by excessive groundwater withdrawal in this area.

\section{Desalinization}

Desalinization is described here as an improvement in groundwater quality associated with a decrease in $\mathrm{Cl}^{-}$concentration relative to $\mathrm{HCO}_{3}^{-}$. An increase in the $\mathrm{HCO}_{3}{ }^{-} / \mathrm{Cl}^{-}$ ratio with time would suggest flushing, and subsequent displacement or removal of saline groundwater. We will use the data from Winter Cove to illustrate that this process is likely occurring on Saturna Island.

Winter Cove is comparatively a developed area of the island, but lot sizes are larger than those in similarly built-up areas (e.g., East Point peninsula). As a result, groundwater use in the Winter Cove subregion is not as concentrated. Groundwaters collected from the northern properties (WC-4, WC-6, WC-7, WC-8, WC-9, WC-13, WC-14, WC-15, and WC-BP) are identified with open circles in the Piper plot (Fig. 6b), whereas samples collected from the southern properties are identified with solid circles (WC-1, WC-2, WC-3, WC-5, WC-10, WC-11, and WC-12). The southern samples, situated up geological dip (Fig. 3), are generally more immature, as they have lower EC values. These waters plot similarly to other immature waters on the island, with the exception of WC-11 and WC-3. WC-11 was collected from a well that is approximately the same depth as other wells in Winter Cove. WC-3, with higher $\mathrm{SO}_{4}{ }^{2-}$ than $\mathrm{Cl}^{-}$, was collected from a very shallow well right near the coast. Most northern samples have $\mathrm{Ca}^{2+}$ as the dominant cation, which agrees with the earlier conclusion that cation exchange does not appear to be a dominant process in the Winter Cove area. With the exception of WC-BP, these waters have moderate $\mathrm{Cl}^{-}$and have significantly higher concentrations of $\mathrm{SO}_{4}{ }^{2-}$ compared with most southern samples.

The limited amount of cation exchange in all of these waters could be explained by a lower residence time. More likely, it is the result of a low number of exchange sites on the predominantly sandstone units at depth. The cause of high sulphate concentrations is less obvious, but a similar ground- 
Fig. 9. Distance along East Point peninsula (inland to coast) versus (a) $\mathrm{Cl} / \mathrm{HCO}_{3}$ molar ratio and $(b) \mathrm{HCO} / \mathrm{Cl}$ molar ratio.
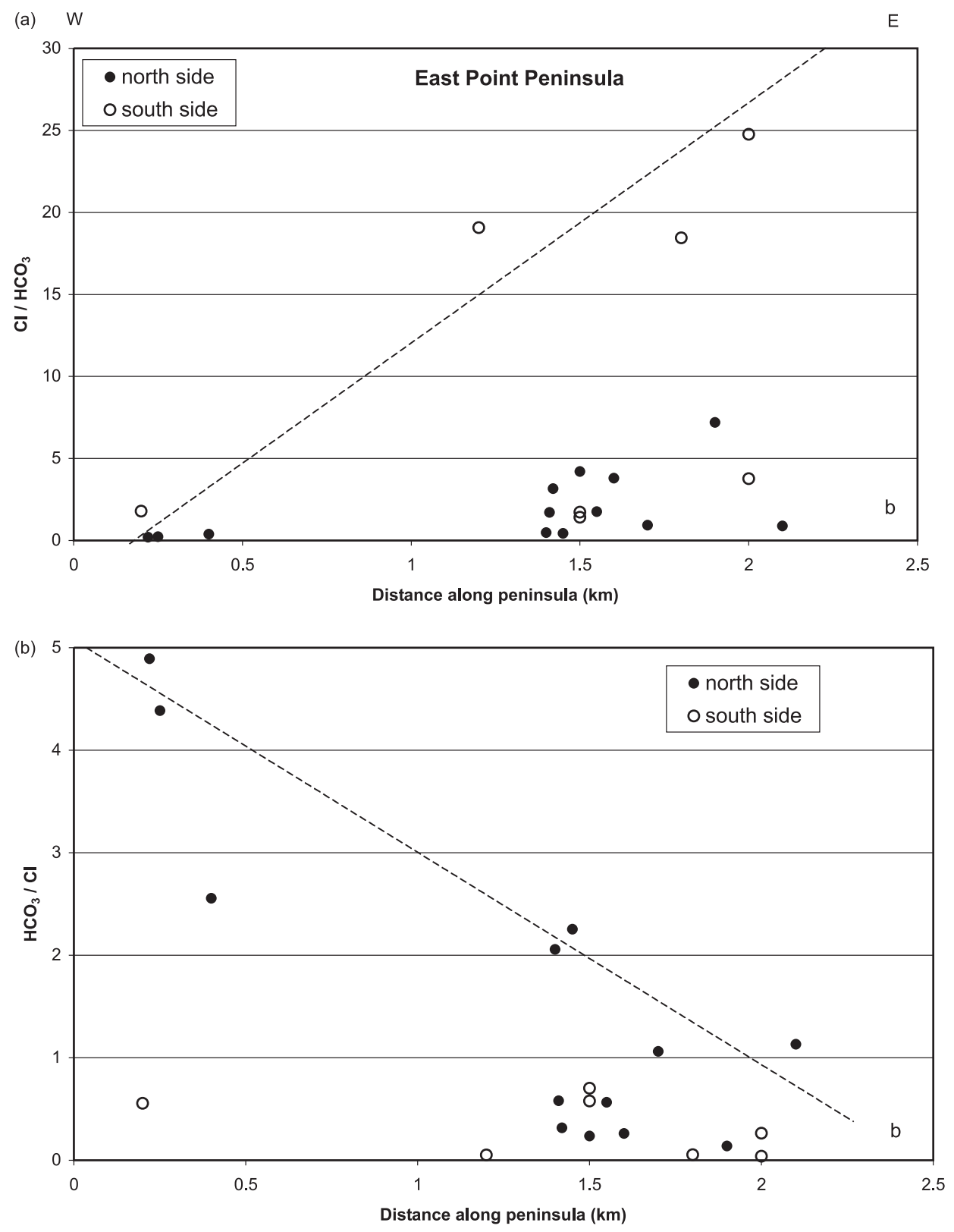

water composition was observed on Mayne Island (Dakin et al. 1983).

Trends in groundwater salinization in Winter Cove were investigated by comparing water analyses from 1981 with those from 1998. When the area was developed in the early 1980 s, the chemistry for each well on every lot was analysed. Data from 12 wells are available for the two sampling times. The concentrations of major ions in 1998 are significantly lower than those in 1981, with the exception that sulphate and calcium have generally increased in concentration. During the past 18 years, EC has decreased by as much as $500 \mu \mathrm{S} / \mathrm{cm}$. Similarly, $\mathrm{Na}^{+}$and $\mathrm{Cl}^{-}$concentrations have decreased by as much as $200 \mathrm{mg} / \mathrm{L}$. Although $\mathrm{Ca}^{2+}$ has increased in concentration by as much as $90 \mathrm{mg} / \mathrm{L}$, in general, concentrations have only changed by $50 \mathrm{mg} / \mathrm{L}$. $\mathrm{HCO}_{3}{ }^{-} / \mathrm{Cl}^{-}$is plotted against EC (Fig. 10) to illustrate the overall trend. Samples exhibiting significant improvement (WC-4, WC-6, WC-11, and WC-14) are located on the north half of the subregion. The likely cause of improved quality is groundwater flushing, which is evident as an increase in $\mathrm{HCO}_{3}{ }^{-} / \mathrm{Cl}^{-}$. As this area was previously undeveloped, the groundwater system was closer to equilibrium because groundwater was not being extracted. With a lower circulation rate, the groundwater residence time was likely longer, and the potential for greater alteration due to chemical reactions like calcite dissolution increased. Since the land was put to residential use, the older more evolved groundwater has been pumped out, and younger water has replaced it. An interesting point is that groundwater samples taken from properties overlooking Lyall Harbour (south side) have only changed slightly or not 
Fig. 10. $\mathrm{HCO}_{3} / \mathrm{Cl}$ molar ratio versus electrical conductivity (EC) for Winter Cove groundwaters sampled in 1981 and 1998.

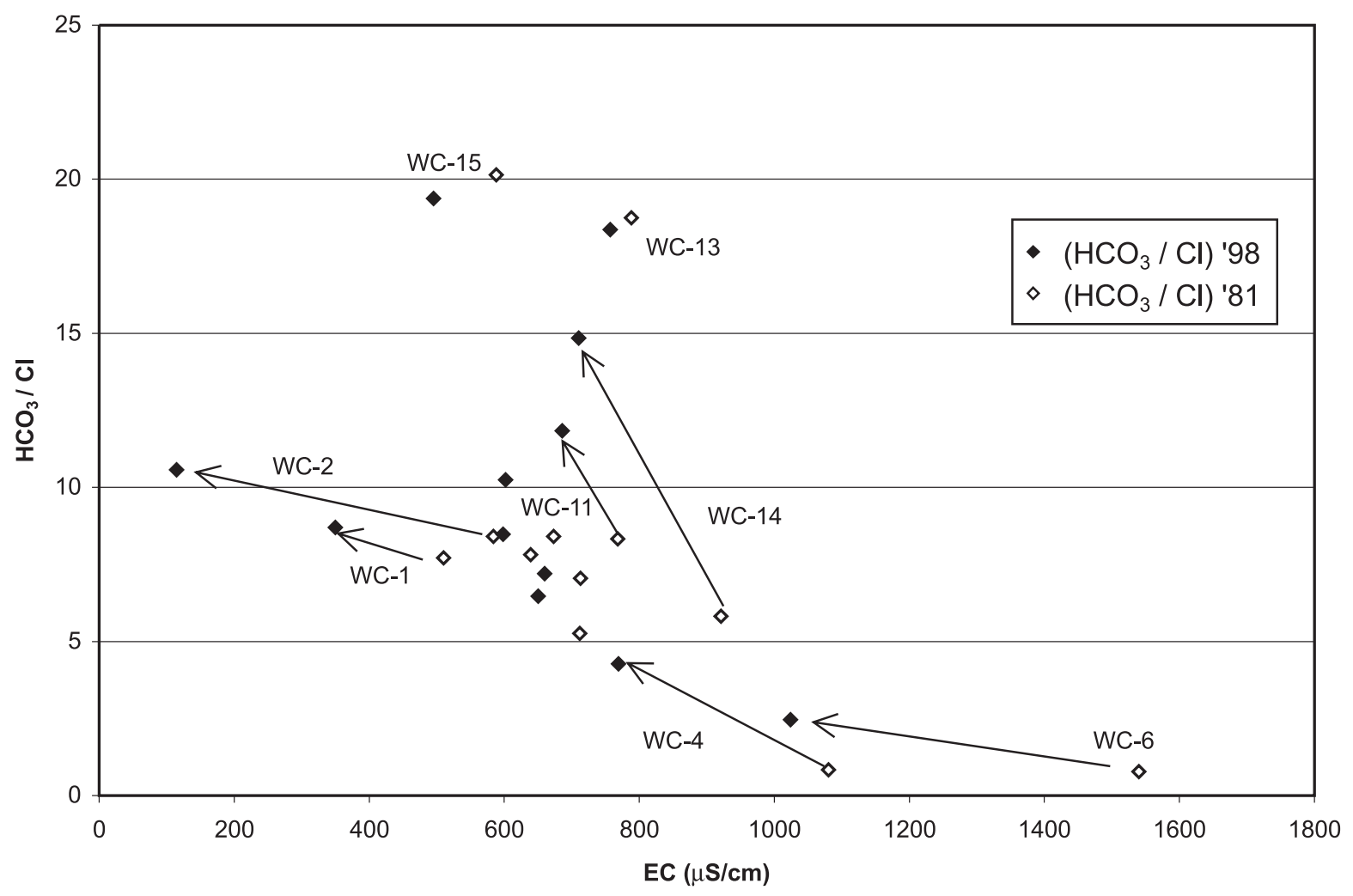

at all. One possible reason for this is that natural groundwater circulation is probably down geological dip, and the up-dip area might have been flushed before the development took place.

\section{Geologic sources of major ions}

Typically, groundwater at discharge zones has a higher TDS than groundwater in recharge zones because of wateraquifer interactions and possible mixing with older saline water along flow paths. Shallow residual (connate) groundwater is uncommon due to normal flushing of formation water by precipitation. Furthermore, groundwater will become increasingly saline with depth because of chemical interactions with aquifer materials, increased residence times, and mixing.

On Saturna Island, the dissolution of carbonate minerals, feldspar minerals (primarily Na-rich plagioclase), and quartz is expected to influence major-ion composition of groundwater. The presence of dissolved $\mathrm{SiO}_{2}$ in groundwater suggests that crystalline rock fragments form a major component of the aquifer matrix. $\mathrm{SiO}_{2}$ is present in all groundwater at concentrations typically less than $10 \mathrm{mg} / \mathrm{L}$, but ranges from less than $1 \mathrm{mg} / \mathrm{L}$ in surface waters to $25 \mathrm{mg} / \mathrm{L}$ in one groundwater sample. $\mathrm{Na}^{+}$in groundwater can potentially originate from a variety of sources including the dissolution of albite $\left(\mathrm{NaAlSi}_{2} \mathrm{O}_{8}\right)$, clay minerals, seawater, or brine; however, it is unlikely that significant $\mathrm{Na}^{+}$will be derived from feldspar minerals because of their low solubility. Saturation indices calculated using SOLMINEQ® (Alberta Research Council 1988) indicate that most groundwaters on Saturna Island are highly saturated with respect to kaolinite, slightly saturated with respect to gibbsite, and either just below or just above saturation with respect to albite.

The origin of $\mathrm{Ca}^{2+}$ and $\mathrm{Mg}^{2+}$ is likely dissolution of carbonate minerals. $\mathrm{As}_{\mathrm{Mg}^{2+}}$ is present at very low levels with respect to $\mathrm{Ca}^{2+}$, calcite $\left(\mathrm{CaCO}_{3}\right)$ and not dolomite $\left(\mathrm{CaMg}\left(\mathrm{CO}_{3}\right)_{2}\right)$ is likely the dominant mineral present. Some $\mathrm{Mg}^{2+}$ may be lost by cation exchange with $\mathrm{Na}^{+}$, or alternatively, $\mathrm{Mg}^{2+}$ may be contributed by mica.

$\mathrm{HCO}_{3}{ }^{-}$ranges from 28.5 to $412 \mathrm{mg} / \mathrm{L}$. The highest values are measured in the Winter Cove area, and the lowest in East Point. $\mathrm{HCO}_{3}{ }^{-}$is likely derived from the dissolution of calcite and dolomite, probably under closed-system conditions (Fig. 8), with only minor contributions from the soil zone.

$\mathrm{SO}_{4}{ }^{2-}$ levels on Saturna Island are appreciable in a number of samples, but its origin is unclear. Both gypsum $(\mathrm{Ca}$ $\left.\mathrm{SO}_{4} \cdot 2 \mathrm{H}_{2} \mathrm{O}\right)$ and anhydrite $\left(\mathrm{CaSO}_{4}\right)$ can be common sources of $\mathrm{SO}_{4}{ }^{2-}$ in sedimentary environments (Dakin et al. 1983). Although the saturation indices for gypsum and anhydrite are well below zero, this may be the result of loss of $\mathrm{Ca}^{2+}$ through cation exchange. $\mathrm{SO}_{4}{ }^{2-}$ may also have derived from pyrite $\left(\mathrm{FeS}_{2}\right)$ oxidation. Granite clasts in till contain pyrite; however, there is only a thin veneer of till over much of the island. Dakin et al. (1983) proposed that $\mathrm{SO}_{4}{ }^{2-}$ originates from connate waters (assuming they are present). As $\mathrm{SO}_{4}{ }^{2-}$ is found at low concentrations in most parts of the island where $\mathrm{Cl}^{-}$is high, it is unlikely that a connate source for $\mathrm{SO}_{4}{ }^{2-}$ is likely. An alternative hypothesis is that $\mathrm{SO}_{4}{ }^{2-}$ originates from small amounts of gypsum precipitated at the surface during the long dry periods when there is no precipitation or perhaps as a result of intensive irrigation. The fact that Winter Cove has a fairly large farm at its centre 
may provide an explanation for irrigation-related $\mathrm{SO}_{4}{ }^{2-}$. At this time, it is not possible to provide definitive evidence for the origin of sulphate in the water. Sulphur isotopes may provide useful information in future studies.

In an attempt to explain the origin of dissolved $\mathrm{Cl}^{-}$, the study conducted on Mayne Island is used for comparison. Dakin et al. (1983) reported the results of leach tests conducted on rock cuttings collected in three boreholes on Mayne Island. On the basis of these leach tests and the geochemical data, it was concluded that major ions such as $\mathrm{Cl}^{-}$, $\mathrm{Na}^{+}$, and $\mathrm{SO}_{4}{ }^{2-}$ could be originating from connate pore fluids. The Mayne Island data were insufficient to narrow the cause, but three possible sources were hypothesized as being responsible for observed ion concentrations: (i) pore water that was trapped during shale deposition in a marine environment; (ii) emplacement of sodium and chloride by brines during the Tertiary when Nanaimo Group rocks were buried beneath several kilometres of material; and (iii) in shallow zones, sodium and chloride entered bedrock from seawater intrusion during the Pleistocene when eustatic and isostatic changes caused submergence of present outcroppings.

Dakin et al. (1983) calculated that $\mathrm{Na}^{+}$and $\mathrm{Cl}^{-}$could originate in the shale units at concentrations that could support long-term release to the circulating groundwater, and be released by diffusion through sandstone and into the fractures over many thousands of years. The fractures would undergo significant flushing, and a concentration gradient could be maintained through the rock mass. Shallow bedrock units would be flushed, and at the present time would contain little remaining salt, while deeper bedrock would still remain at high salinity. However, if this diffusion hypothesis is correct, then on Saturna Island not only should there be a higher incidence of saline groundwaters in areas where shale units are dominant, but also the highly saline groundwaters would be restricted to deeper wells. We do not see these patterns. Further, it should be noted that all three boreholes used for leaching of rock cuttings were located in the central part of Mayne Island in the primary area of known high salinity associated with a fault zone. This fault zone may serve as a trap or conduit for saline waters and may not be representative of the aquifer composition elsewhere.

In comparison to Mayne Island, $\mathrm{Cl}^{-}$and $\mathrm{Na}^{+}$concentrations in groundwater on Saturna Island are much lower than those reported by Dakin et al. (1983). As well, $\mathrm{SO}_{4}{ }^{2-}$ concentrations are elevated on Mayne Island and plot similarly in the Piper plot to data for Winter Cove. The geological structure and topographic expression of the two islands may be partially responsible for the observed differences. Cation exchange appears to be a dominant process on both islands (Fig. 5). The source for exchange of $\mathrm{Na}^{+}$is likely clay minerals within the mudstone horizons of the massive sandstone units (perhaps with the exclusion of the de Courcy Formation because of its uniform sand composition).

One alternative explanation for the saline chemical composition of groundwater is salt-water intrusion. Dakin et al. (1983) discounted salt-water intrusion as a major factor in the origin of salinity because the results on Mayne Island did not appear to support this process. We will attempt to show in the following discussion of the hydrochemical results that salt-water intrusion can account for a significant number of salinization problems on Saturna, but that recognition of the process is complicated by preexisting sources of salinity.

\section{Discussion}

In coastal areas, where aquifers are in direct contact with seawater, the denser seawater tends to form an infiltrating wedge below the less dense overlying fresh water. The location of the seepage face at depth is dependent upon the density variations between fresh and salt water and the fresh groundwater flux moving from inland out to the coast (Freeze and Cherry 1979). A transitional zone of variable thickness represents the contact between fresh and saline water.

Seawater intrusion, recognized by the higher incidence of extracted saline groundwater in coastal aquifers, can occur for a number of reasons. Typically, salt-water intrusion occurs as a result of disruptions to equilibrium conditions and is accompanied by a temporal deterioration of water quality. However, if a well breaches the transition zone during drilling, saline groundwater may be encountered immediately. The onset of salt-water intrusion can be caused by wells pumping at sufficiently high rates or by many wells actively pumping in a high-density development area. In this instance, salt water can be drawn upwards from the fresh water - salt water interface (upconing) or may be drawn directly from the ocean through permeable units under the reversed gradient. Intrusion of seawater likely will be enhanced in bedrock aquifers as a result of the preferential movement of seawater inland along bedding planes and major fractures. The equilibrium can also be disrupted if the volume of fresh water entering the recharge zone decreases due to excessive development, whereby the recharge zone is cut off.

In a well with a salinity that is high due to salt-water intrusion, the mole ratios of the various constituents will be similar to those of ocean water. Variations in mole ratios may reflect a mixing with local groundwaters. Several groundwater samples from this study have extremely high EC values and plot immediately beneath ocean water in the Piper plot (EP-6, EP-27, EP-29C, MD-2, NB-3, WC-BP, MD-2, and NB-3). Because these wells are proximal to the shoreline, and other neighbouring wells do not have the same characteristics, salt-water intrusion is the likely cause of salinity.

The bivariate plot for $\mathrm{Na}^{+}$and $\mathrm{Cl}^{-}$(Fig. 11) shows that most high-conductivity samples plot along a fresh water (spring BB-2) - seawater mixing line. Most East Point groundwater samples have high concentrations of both $\mathrm{Na}^{+}$ and $\mathrm{Cl}^{-}$and lie near the mixing line, suggesting that a major proportion of the groundwater in this region is mixing with seawater. The fact that most waters, particularly at low to moderate concentrations, plot above the mixing line indicates additional sources of $\mathrm{Na}^{+}$, most likely cation exchange. At higher concentrations, the deviation is less apparent because of the logarithmic scale used for plotting.

To illustrate the possible evolution of groundwater as it mixes with ocean water, a simple (conservative) geochemical mixing model was used. Figure 12 shows the results of mixing ocean water and each of samples BR-2 and SB-4 (from 
Fig. 11. Bivariate plot for $\mathrm{Na}$ versus $\mathrm{Cl}$. Seawater mixing line shown for concentrations of $\mathrm{Cl}$ greater than $100 \mathrm{mg} / \mathrm{L}$.

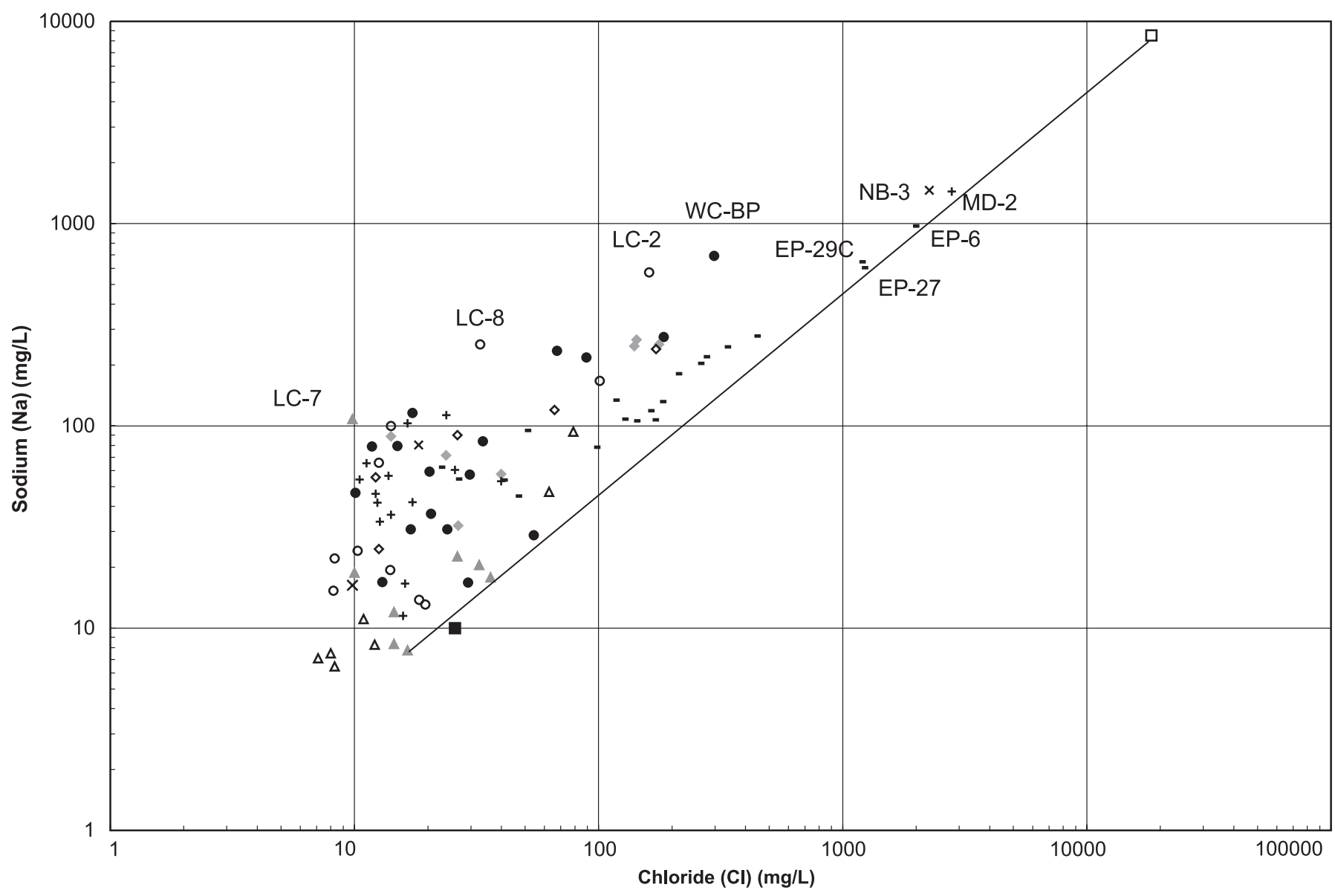

Plumper Sound) in various ratios. BR-2 was selected as an end member because it is characteristic of an intermediatecomposition water that has gone through cation exchange, possibly prior to mixing, while SB-4 represents a typical fresh groundwater. The evolution trajectories show that if ocean water mixes with groundwater at any percentage higher than 5 , then the composition of the groundwater will reflect that of the ocean water. Further, cation exchange processes $\left(\mathrm{Ca}^{2+}\right.$ to $\mathrm{Na}^{+}$shift $)$account for more Na-rich end waters compared to seawater (i.e., most saline waters plot below seawater in the diamond).

A remaining question relates to the origin of the $\mathrm{Na}^{+}$that appears to be plentiful at depth in the bedrock units. As stated earlier, it is likely that $\mathrm{Na}^{+}$is situated on exchange sites, such as in the shale beds within the massive sandstone units. When fresh meteoric groundwater infiltrates the subsurface, it will first dissolve calcite and (or) gypsum because these minerals have relatively high solubilities. $\mathrm{Na}^{+}$-rich feldspar will also begin to dissolve, but at a much slower rate. When the $\mathrm{Ca}^{2+}$-rich water comes into contact with shale horizons, the process of cation exchange is initiated. We might speculate that the longer the residence time (i.e., the deeper and more prolonged the circulation), the more cation exchange will occur, provided exchange sites are available. Shallow groundwater circulation will not likely result in extensive cation exchange because the sites already have been occupied by $\mathrm{Ca}^{2+}$. On Saturna Island, we observe that most shallow groundwaters undergo no cation exchange, whereas intermediate-depth waters (collected from deep wells in recharge areas, and some wells situated up slope from the coast) show evidence of cation exchange but no salinization.

One process that may account for the high $\mathrm{Na}^{+}$currently adsorbed to the clays dates back to the Pleistocene. One can speculate that during the Pleistocene, when the Gulf Islands were submerged (Clague 1983; Mathews et al. 1970), ocean water intruded into the bedrock units, filling all the pores and fractures. This water would have remained resident for a long period of time (probably on the order of several tens of thousands of years), giving ample time for groundwater to attain equilibrium with the surrounding rock mass. Reverse cation exchange (water hardening), in which $\mathrm{Na}^{+}$-rich seawater exchanges for $\mathrm{Ca}^{2+}$ on exchange sites, or alternatively, just saturation of exchange sites by $\mathrm{Na}^{+}$-rich intruded water may have taken place during island submergence. Reverse cation exchange has been observed in many localities where modern salt water is being intruded (e.g., Monterey, California (D.K. Todd Consulting Engineers Inc. 1989), and Manhattan Beach area, California (Brennan 1956)). This process would have left a significant amount of $\mathrm{Na}^{+}$on shale exchange sites. In addition, a significant amount of other constituents found in seawater would have remained in the pores. Once the islands became exposed following isostatic rebound at the end of the Pleistocene, fresh meteoric water would have 
Fig. 12. Piper diagram showing mixing of ocean water and samples BR-2 and SB-4 (Plumper Sound flow region on south side of Saturna Island).

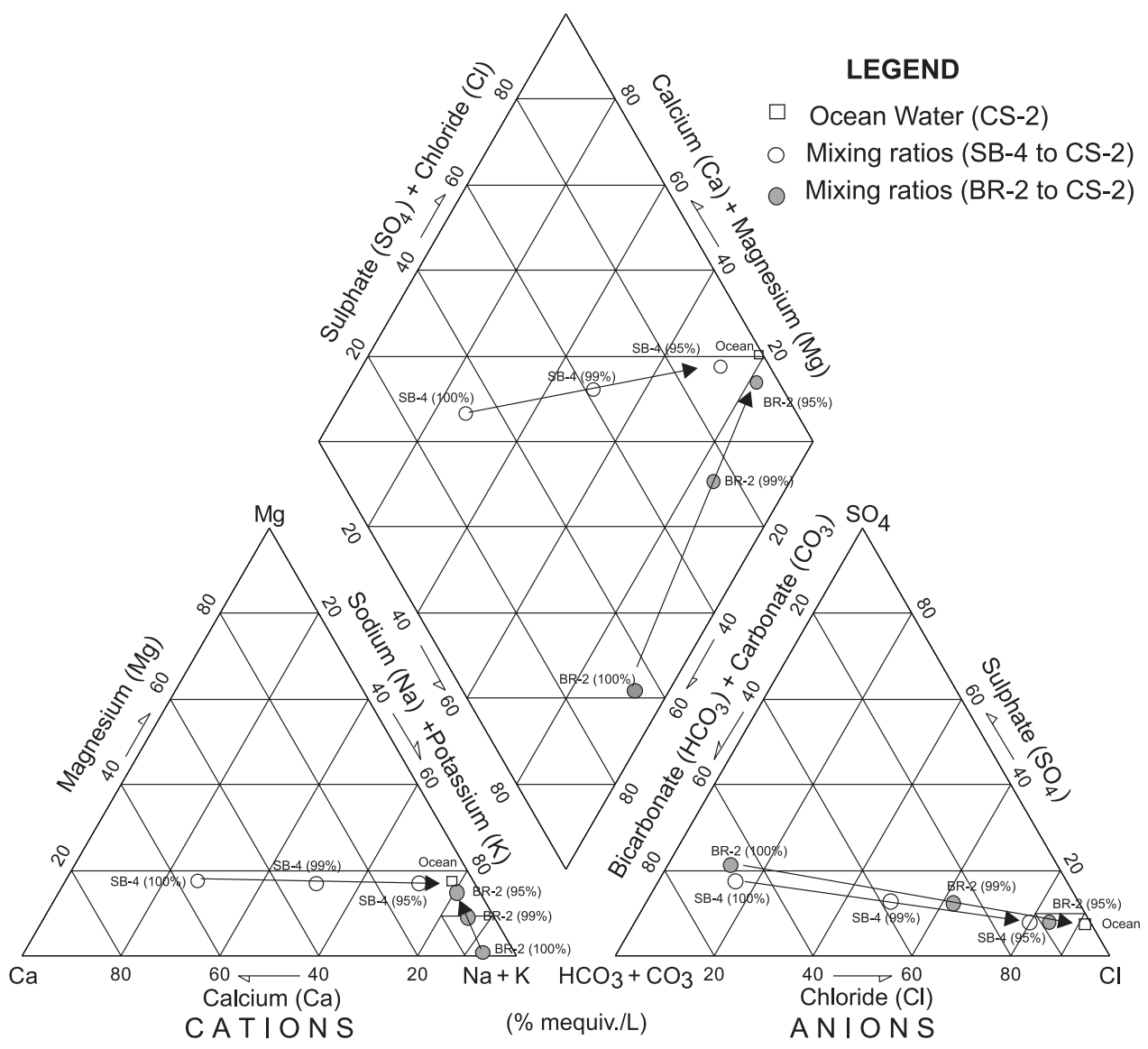

begun to flush out the more mobile constituents like $\mathrm{Cl}^{-}$and $\mathrm{SO}_{4}{ }^{2-}$. This process is likely still ongoing and represents a form of natural desalinization at a larger, island scale (the desalinization process proposed is similar to that observed at present in Winter Cove). In comparison, $\mathrm{Na}^{+}$would be more difficult to mobilize, and only over a long period with a steady supply of $\mathrm{Ca}^{2+}$ and (or) $\mathrm{Mg}^{2+}$ would $\mathrm{Na}^{+}$become desorbed.

On Saturna Island, however, there is clear indication that several shallow wells are highly saline. Typically, these wells are situated near the coastline, suggesting that they have penetrated the fresh water - salt water interface. The chemical composition of the highly saline wells is either the result of immature groundwater $\left(\mathrm{Ca}-\mathrm{HCO}_{3}\right.$ type $)$ mixing with seawater (e.g., EP-6, EP-27A, and EP-29C), which results in a chemical composition that reflects the higher $\mathrm{Ca}^{2+}$ content (i.e., samples plot slightly above ocean water in the Piper plot), or mature groundwater (e.g., EP-23, BR-2) mixing with seawater, which reflects the higher $\mathrm{Na}^{+}$content (i.e., samples plot slightly below ocean water in the Piper plot).

\section{Conclusions}

The chemical character of most surface waters, springs, and immature groundwaters (low EC values) on Saturna Island suggests that groundwater is recharged locally, typically at high elevation. Most surface waters, particularly swamps, are situated in recharge areas. Except in a few areas (with minor agricultural activity), $\mathrm{P}_{\mathrm{CO}_{2}}$ levels are low to moderate, reflecting the low overburden cover and general absence of organic-rich soil. Shallow groundwater appears to evolve under more or less closed-system conditions and reaches close to saturated conditions with respect to calcite and dolomite. These shallow groundwaters then undergo a compositional change (Ca-rich to Na-rich) as they mature while flowing deeper down. This compositional change can be explained by cation exchange that occurs in clay mineral rich beds associated with most geological formations.

Mature groundwater encounters and mixes with seawater near the shore or residual saline water at depth. This mixing results in a significant increase in EC, reflecting higher concentrations of $\mathrm{Cl}^{-}$and $\mathrm{Na}^{+}$. Water wells that are drilled beyond or completed to depths beneath this zone of mixing experience salt-water intrusion. The occurrence of highly saline groundwaters is not consistent from region to region and depends primarily upon the amount of recharge and patterns of groundwater use.

As cation exchange is dominant at intermediate depths on Saturna Island, we propose that $\mathrm{Na}^{+}$resident on exchange sites was adsorbed to clays during seawater incursion when the island was submerged during the Pleistocene. Since that time, and following isostatic rebound, meteoric waters have infiltrated and flushed the more mobile ions like $\mathrm{Cl}$ from the shallow to intermediate depths (desalinization). At the present 
time, $\mathrm{Na}^{+}$and $\mathrm{Cl}^{-}$remain at depth and in discharge areas along the coast. The extraction and replacement of residual saline waters with fresh waters (desalinization) appear to be ongoing in Winter Cove, as reflected by salinity declines since 1981.

\section{Acknowledgments}

The authors wish to thank the Saturna Island Local Trust Committee for providing financial assistance for the research project, and the Islands Trust for providing us with a digital base map of Saturna Island. We would also like Brian and Jane Dixon-Warren and Marion and Lorne Bolton for providing lodging during the field season.

\section{References}

Alberta Research Council. 1988. SOLMINEQ.88 PC/Shell manual and software. Alberta Research Council, Oil Sands and Hydrocarbon Recovery, Edmonton, Alta.

Allen, D.M., and Michel, F.A. 1998. Evaluation of multi-wells test data in a faulted aquifer using linear and radial flow models. Ground Water, 36: 938-948.

Allen, D.M., and Michel, F.A. 1999. Characterizing a faulted aquifer by field testing and numerical simulation. Ground Water, 37: 718-728.

Brennan, R. 1956. Sea-water intrusion in California — preliminary chemical quality study in the Manhattan Beach area, California. California Department of Water Resources, Bulletin 63, Appendix E.

Canadian Air and Precipitation Monitoring Network. 2000. CAPM81414A, Saturna. <http://airquality.tor.ec.gc.ca/natchem/>.

Clague, J.J. 1983. Glacio-isostatic effects of the Cordilleran Ice Sheet, British Columbia. In Shorelines and isostasy. Edited by D.E. Smith and A.G. Dawson. Academic Press, London, England, pp. 321-343.

Clague, J.J. 1986. The Quaternary stratigraphic record of British Columbia - evidence for episodic sedimentation and erosion controlled by glaciation. Canadian Journal of Earth Sciences, 23: $885-894$.
Dakin, R.A., Farvolden, J.A., Cherry, J.A., and Fritz, P. 1983. Origin of dissolved solids in groundwater of Mayne Island, British Columbia, Canada. Journal of Hydrology, 63: 233-270.

Dixon-Warren, A. 1997. Quaternary geology of Saturna Island. Department of Earth Sciences, Simon Fraser University, Burnaby, B.C.

D.K. Todd Consulting Engineers Inc. 1989. Sources of saline intrusion in the 400-foot aquifer, California area, California. Report to the Monterey County Flood \& Water Conservation District. D.K. Todd Consulting Engineers Inc., Berkeley, Calif.

England, T.D.J., and Hiscott, R.N. 1992. Lithostratigraphy and deep-water setting of the upper Nanaimo Group (Upper Cretaceous), outer Gulf Islands of southwestern British Columbia. Canadian Journal of Earth Sciences, 29: 574-595.

Environment Canada. 1982. Canadian Climate Normals: temperature and precipitation 1951-1980. Vol. 1. British Columbia. Canadian Climate Centre, Downsview, Ont.

Fontaine, J. 1982. The geohydrology of Saturna Island. B.Sc. thesis, University of Victoria, Victoria, B.C.

Freeze, R.A., and Cherry, J.A. 1979. Groundwater. Prentice-Hall Inc., Englewood Cliffs, N.J.

Hodge, W.S. 1985. A preliminary assessment of groundwater conditions on Saturna Island, British Columbia. Water Management Branch, British Columbia Ministry of Environment, Victoria, B.C.

Mathews, W.H., Fyles, J.C., and Nasmith, H.W. 1970. Post-glacial crustal movements in southwestern British Columbia and adjacent Washington State. Canadian Journal of Earth Sciences, 7: 690-702.

Mustard, P.S. 1994. The Upper Cretaceous Nanaimo Group, Georgia Basin. In Geology and geological hazards of the Vancouver region, southwestern British Columbia. Edited by J.W.H. Monger. Geological Survey of Canada, Bulletin 481, pp. 27-95.

Richter, B.C., and Kreitler, C.W. 1993. Geochemical techniques for identifying sources of ground-water salinization. CRC Press, Boca Raton, Fla.

Suchy, M. 1998. Physiographic and Geological Controls on Groundwater Salinity variations on Saturna Island, B.C. Unpublished BSc thesis, Department of Geography, Simon Fraser University, Burnaby, B.C. 